Article

\title{
Cleaner and Sustainable Energy Production in Pakistan: Lessons Learnt from the Pak-TIMES Model
}

\author{
Syed Aziz Ur Rehman ${ }^{1} *\left(\mathbb{D}\right.$, Yanpeng Cai ${ }^{2}$, Zafar Ali Siyal ${ }^{3}$, Nayyar Hussain Mirjat ${ }^{4}$, \\ Rizwan Fazal ${ }^{5}$ and Saif Ur Rehman Kashif ${ }^{1}$ \\ 1 Department of Environmental Sciences, University of Veterinary and Animal Sciences, Lahore 54000, Punjab, \\ Pakistan; rehman.kashif@uvas.edu.pk \\ 2 State Key Laboratory of Water Environment Simulation, School of Environment, Beijing Normal University, \\ Beijing 100875, China; yanpeng.cai@bnu.edu.cn \\ 3 Department of Energy and Environment Engineering, Quaid-e-Awam University of Engineering, \\ Science and Technology, Nawabshah 67480, Sindh, Pakistan; zafarsiyal@quest.edu.pk \\ 4 Department of Electrical Engineering, Mehran University of Engineering and Technology, Jamshoro 76062, \\ Sindh, Pakistan; nayyar.hussain@faculty.muet.edu.pk \\ 5 Pakistan Institute of Development Economics (PIDE), Quaid-e-Azam University Campus, Islamabad 44000, \\ Pakistan; rizwanfazal_15@pide.edu.pk \\ * Correspondence: syed.aziz@uvas.edu.pk; Tel.: +92-333-5568438
}

Received: 25 November 2019; Accepted: 19 December 2019; Published: 24 December 2019

\begin{abstract}
The energy planning process essentially requires addressing diverse planning objectives, including prioritizing resources, and the estimation of environmental emissions and associated health risks. This study investigates the impacts of atmospheric pollution for Pakistan from the energy production processes under various modalities. A national-scale bottom-up energy optimization model (Pak-TIMES) with the ANSWER-TIMES framework is developed to assess the electricity generation pathways (2015-2035) and estimate GHG emissions and major air pollutants, i.e., $\mathrm{CH}_{4}$, $\mathrm{CO}, \mathrm{CO}_{2}, \mathrm{~N}_{2} \mathrm{O}, \mathrm{NO}_{\mathrm{X}}, \mathrm{PM}_{1}, \mathrm{PM}_{10}, \mathrm{PM}_{2.5}, \mathrm{PM}_{\mathrm{BC}}, \mathrm{PM}_{\mathrm{OC}}, \mathrm{PM}_{\mathrm{TSP}}, \mathrm{SO}_{2}$, and $\mathrm{VOC}$ under five scenarios. These scenarios are: BAU (business-as-usual), RE-30 (30\% renewables), RE-40 (40\% renewables), Coal-30 (30\% coal), and Coal-40 (40\% coal). It is revealed that to reach the electricity demand of $3091 \mathrm{PJ}$ in 2035, both the Coal-30 and Coal-40 scenarios shall cause maximum emissions of GHGs, i.e., 260.13 and $338.92 \mathrm{Mt}$ (million tons) alongside 40.52 and $54.03 \mathrm{Mt}$ emissions of $\mathrm{PM}_{\mathrm{TSP}}$ in both of the scenarios, respectively. BAU scenario emissions are estimated to be $181.5 \mathrm{Mt}$ (GHGs) and $24.30 \mathrm{Mt}\left(\mathrm{PM}_{\mathrm{TSP}}\right)$. Minimum emissions are estimated in the RE-40 scenario with $96.01 \mathrm{Mt}$ of GHGs and $11.80 \mathrm{Mt}$ of $\mathrm{PM}_{\mathrm{TSP}}$, followed by the RE-30 scenario (143.20 GHGs and 17.73 Mt PM $\mathrm{TSP}_{\mathrm{TS}}$ ). It is, therefore, concluded that coal-based electricity generation technologies would be a major source of emission and would contribute the highest amount of air pollution. This situation necessitates harnessing renewables in the future, which will significantly mitigate public health risks from atmospheric pollution.
\end{abstract}

Keywords: atmospheric pollution; energy; GHG emissions; Pakistan; Pak-TIMES

\section{Introduction}

Pakistan, like many developing countries, has witnessed substantial growth in the population over the last two decades. This growth in Pakistan's context has also caused growing urbanization accompanied with a significant increase in the number of vehicles, and some development of the industry. This situation has increased the demand for energy and in particular electricity. Since meeting energy demands does not often come without an energy conversion process, as such, the levels of atmospheric pollution along with the sources of air pollutants has increased significantly over the years [1-3]. The levels of air pollution recorded by the Pakistan Environmental Protection 
Agency (Pak-EPA) across various cities in the country have been reported to be approximately seven times higher than the recommended air quality standards of the World Health Organization (WHO). The leading causes of the deteriorated air quality include but are not limited to: Energy inefficiency across demand sectors, unplanned industrial activity, sporadic increase in a number of vehicles, environmental non-compliance by both point and non-point sources of pollutants, and inadequate air quality control measures [3-6]. As such, the air quality in urban centers of the country is distressing compared to rural areas [7]. Various studies have identified that some of the urban centers, especially Lahore, are amongst the most polluted cities in the region [8]. According to some estimates, air pollution-related chronic diseases, mostly respiratory illnesses, are the cause of approximately $2 \%$ ( 1250) deaths in Lahore city in recent years [8,9].

Air pollution is caused by the emission of pollutants, which include both gaseous $\left(\mathrm{NO}_{2}, \mathrm{SO}_{2}\right.$, ozone) and solid forms, such as particulate matter (PM). However, due to the size of PM, and its vulnerability to reach extremities of the respiratory tract, PM with aerodynamic diameters below 10 or $2.5 \mu \mathrm{m}$, i.e., $\mathrm{PM}_{10}$ and $\mathrm{PM}_{2.5}$, respectively, are regarded as more dangerous [10,11]. Moreover, $\mathrm{PM}$ is a highly reactive substance and provides a surface area for various heavy metals, thus raising another major concern of inferior air quality and human health $[9,12]$. Other forms of major atmospheric aerosols species include sulfate $\left(\mathrm{SO}_{4}{ }^{2-}\right)$, nitrate $\left(\mathrm{NO}^{3-}\right)$, ammonium $\left(\mathrm{NH}_{4}{ }^{+}\right)$, black carbon (BC), and organic carbon (OC) $[13,14]$. It has been reported that the concentrations of $\mathrm{PM}, \mathrm{SO}_{2}, \mathrm{CO}, \mathrm{NO}_{2}$, and $\mathrm{Pb}$ in various cities across Pakistan have surpassed the safer limits defined by $\mathrm{WHO}$, except for the $\mathrm{O}_{3}$ concentration, which is within the WHO limits [1]. Compared to other developing countries, air quality standards in Pakistan, especially in urban areas, are also getting poorer each day due to a lack of sufficient ambient air quality monitoring stations [15]. As such, air quality monitoring and quality control programs are extremely important due to the associated negative impacts of air pollutants on humans, plants and wildlife health, and visibility, alongside its interconnection with the global climate [16].

Various well-known human activities, which contribute to the emission of airborne particulate matter (aerosols), include processes involved in petroleum refineries, energy conversion including power generation, vehicular emissions (buses, trucks, cars), industrial activities (building, mining, manufacturing of cement, ceramic and bricks, smelting), and the burning of biomass and agricultural activities to name a few $[17,18]$. All these activities, causing atmospheric emissions, are currently underway in Pakistan. Amongst these activities, electricity generation from thermal power plants while burning of fossil fuel is a key contributor to such emissions. These thermal power stations are also one of the major sources for $\mathrm{NOx}, \mathrm{SO}_{2}, \mathrm{PM}$, and greenhouse gases (GHG) emissions. The emission of air pollutants from thermal power plants is a function of various parameters, such as technological nature (evolutionary or revolutionary), plant capacity, input fuel, the age of the plant, plant technical life, operation and maintenance standards, and other such factors. There is a large number of thermal power plants, mostly independent power producers (IPPs), that are currently operational in Pakistan, with more plants in the center and southern parts of the Punjab province [19].

Pakistan is not a huge emitter of GHG on a worldwide scale and contributed around $0.8 \%$ of the total global GHG, with 45 million tons (Mt) $\mathrm{CO}_{2}$ emissions from the power generation sector, in 2014 [20]. It is further estimated that oil-based power plants contributed $65 \%$ of the total $\mathrm{CO}_{2}$ emissions followed by $32 \%$ from natural gas-fired power plants. However, these figures are subject to change in Pakistan due to significant changes in the future energy fuel mix for power generation. In this context, it is pertinent to refer to the government plans of adapting coal-based technologies for electricity generation in recent years due to the prevailing energy crisis. Hence, coal power projects, such as Sahiwal coal power plant, Sheikhupura coal power plant, and Qadirpur coal power plant, are in the construction phase, and upon completion, they shall not only add power to the national grid but at the same time release great levels of emissions [21]. Coal-based power plants are notorious for air pollution both in the form of primary (direct emission) and secondary (gas-to-particle conversion) particulate pollutants emissions. Similarly, the emissions associated with coal combustion depends on 
coal quality, technology in practice followed by meteorological conditions [22,23]. Moreover, the nearby coal power plants of neighboring India are already considered as a recognized source of transboundary air pollution in north-eastern Pakistan [15]. Hence, it is inevitable to assess, quantify, and evaluate the environmental hazards associated with coal power plants and the government's plans of energy and technology mix for electricity generation.

This study is thus the first of its kind which undertakes the estimation of emissions of major air pollutants from energy transformation processes in the country. This attempt, therefore, will help the government and policymakers in making key decisions regarding future energy fuel mix. The paper is structured to assess the environmental and health impacts of energy transformation processes, especially for the atmospheric pollution impacts from energy and technology mix for electricity generation in Pakistan. In this context, TIMES (the integrated MARKAL EFOM system) modeling framework for energy accounting and modeling on a national scale with the bottom-up approach is used in this study. The developed model named Pak-TIMES provides air pollutants emission estimates for 13 pollutants, i.e., $\mathrm{CH}_{4}, \mathrm{CO}, \mathrm{CO}_{2}, \mathrm{~N}_{2} \mathrm{O}, \mathrm{NO}_{\mathrm{X}}, \mathrm{PM}_{1}, \mathrm{PM}_{10}, \mathrm{PM}_{2.5}, \mathrm{PM}_{\mathrm{BC}}, \mathrm{PM}_{\mathrm{OC}}$, $\mathrm{PM}_{\mathrm{TSP}}, \mathrm{SO}_{2}$, and VOC, under five scenarios, namely, BAU (business as usual), $\mathrm{RE}-30$ ( $30 \%$ renewables without hydro), RE-40 ( $40 \%$ renewables without hydro), Coal-30 (30\% coal-based power), and Coal-40 ( $40 \%$ coal-based power). The scope of this paper, therefore, pertains to an analysis of the results of the Pak-TIMES model, which takes into account the electricity generation pathways and compares the air pollutants' impacts under various technological choices for electricity generation in the future (2015-2035).

The next section of this paper provides detailed information with regards to air quality and atmospheric pollution in Pakistan (Section 2), the future of GHG emission reduction in Pakistan is discussed in Section 3, an overview of the energy and electricity sector in Pakistan is elaborated in Section 4, the methodological and theoretical framework of this study is discussed in depth in Section 5, the results and discussion are presented in Section 6, and finally the conclusions and policy recommendations are contained in Section 7.

\section{Air Quality and Atmospheric Pollution in Pakistan: A Brief Literature Survey}

The current population growth rate in Pakistan is about $2.4 \%$ per year whereas $54 \%$ of the energy demand is fulfilled using fossil fuel supplies comprising of oil, natural gas, and coal; the remaining demand energy is met from other sources, such as biomass, agricultural residues, and fuelwood [24-27]. It is estimated that $70 \%$ of the rural population uses biomass and fuelwood to meet their energy needs, with the majority share of fuelwood estimated to be $53 \%$ and followed by biomass supplies of $43 \%$. Both of these fuels are mainly used for cooking and in some cases for other purposes. It has been further estimated that around $20 \%$ of the household's income in rural Pakistan is spent on procuring the fuelwood. According to UN estimates in 2010 alone, about 29.2 million cubic meters of fuelwood was consumed in Pakistan $[24,28]$. Alongside fuelwood, the consumption of the agricultural biomass also poses an air pollution alarm in rural areas due to the associated pollutant emissions of various forms $[29,30]$. On the other hand, in semi-urban and some urban areas, the major sources of air pollution are the traditional small-scale and unorganized brick kiln industries. These units use a range of burnable materials as a source of fuel, such as coal, wood, oil, rubber tires, rice husk, rice straw, corncobs, and bagasse, etc., which results in a wide range of emissions into the atmosphere [31]. Similarly, vehicular and industrial emissions are the predominant sources of air pollution in urban areas and megacities. According to the 2013-2014 economic survey, the number of vehicles in Pakistan has increased at the rate of $130.3 \%$ per year in the country during the period 2001-2013. Punjab is the largest province in the country, and in 2010 alone, the registered number of vehicles in the province was recorded to be 7,483,860 [32].

The nature of gaseous and particulate emissions from the above-discussed activities is not contrastingly different. Therefore, studies that focus on air pollution always attempt at tracing the sources of air pollutants along with the share from each source termed as source identification and 
apportionment. Hence, air pollutants are often traced back to their sources, which can be both stationary, such as power plants, industries, incinerators, and residential heating, or mobile/non-stationary, e.g., vehicles. From the chemical composition point of view, air pollutants can be either organic or inorganic; the latter includes trace metals, such as arsenic, cadmium, chromium, and lead. Therefore, inorganic pollutants are regarded as highly toxic (e.g., carcinogenic) and are always focused [21]. The organic contaminants are mostly those with pro-oxidant characteristics, e.g., polycyclic aromatic hydrocarbons (PAHs), volatile organic compounds (VOCs), and heavy metal complexes, all of which are mainly vehicular emissions [33]. However, due to the nature of atmospheric pollutants being highly reactive, the pollutants eventually adapt both solid and gaseous properties termed as aerosols. Aerosols and the precursors of aerosols are released both in natural and anthropogenic processes, such as vehicular transport, power plants, industries, biomass and crop-residue burning, windblown dust, sea spray, biogenic emissions, forest fires and volcanic eruptions [34,35], and off-road vehicle emissions [36]. The formation of aerosols and subsequent complexity is attributed to both the availability of contaminates and meteorological conditions, e.g., complex aerosols are formed as a result of sulfates, nitrates, and organic matter availability [37]. Among the aerosols, black carbon (BC) aerosols emerge as a result of biomass burning and incomplete combustion processes. $\mathrm{BC}$ aerosol is notorious for its radiative properties, i.e., they absorb visible and infrared wavelengths and are responsible for climate perturbation. Thus, $\mathrm{BC}$ is one of the most climatologically significant components of $\mathrm{PM}_{2.5}$ [38,39].

The existing literature provides ample insight into the air quality and atmospheric pollution in some of the major cities of Pakistan. Amongst other urban centers, Karachi and Lahore are of importance, being highly populated. Both of these cities, however, have different geographic and climatic features, yet with respect to air quality levels, they do not differ much. As such, both Lahore and Karachi have surpassed the air pollution standard limits, having exceeding levels of total suspended particulate (TSP) pollutants $[40,41]$. The year-round average $\mathrm{PM}_{2.5}$ in Lahore is about $118 \pm 79 \mathrm{mg} / \mathrm{m}^{-3}$ followed by $84 \pm 21 \mathrm{mg} / \mathrm{m}^{-3}$ in Karachi [42]. Lahore is, therefore, a comparatively more pollutant and highly investigated city regarding air pollution [43]. Besides domestic sources of air pollution, transboundary particulate emissions, e.g., $\mathrm{PM}_{2.5}$ from western India, eastern Afghanistan, and eastern Iran, are also reportedly contributing to the air pollution in the country [42].

The literature under this study identified that Lahore is the most highly studied city regarding air pollution monitoring and investigation $[8,9,11,14,21,32,34,40,43-46]$, followed by Islamabad [2,10,12,17,35,47-52], Karachi [38,39,41,44,53], Peshawar [18,44], Quetta [7], Faisalabad [3], Swat [16], and Wah [13]. A countrywide study pertaining to atmospheric emission was also undertaken by Shahid [15], to investigate seasonal variations of aerosols (sulfate, nitrate, ammonium, organic carbon, black carbon, and $\mathrm{PM}_{2.5}$ ), and its contributions towards domestic anthropogenic and transboundary transport emissions. Similarly, sector-specific (transport, industry, residential, and energy) contributions to aerosol (sulfate, nitrate, ammonium, organic carbon, black carbon) emissions were also estimated by Shahid, et al. [54]. Mir, et al. [55] coupled greenhouse gas and air pollution interactions and synergies (GAINS) model with Pak-IEM and assessed the emissions of $\mathrm{SO}_{2}, \mathrm{NO}_{\mathrm{X}}$, and $\mathrm{PM}_{2.5}$ from Pakistan's energy sector. Similarly, both historical and future emissions of $\mathrm{CO}_{2}$ were estimated by Lin and Ahmad [56], using LMDI (log mean divisia index) method. The details of studies have been compiled in Table S1 in Supplementary Materials.

The brief literature survey highlights the level of air pollution emission in Pakistan and limited studies undertaken to analyze their health impact. It is further revealed that there is no major study pertaining to air pollutant emissions and their health impact from the energy and technology choices from the possible power generation scenarios of the future.

\section{The Future of GHG Emissions Reduction in Pakistan}

Pakistan is party to UNFCCC (United Nations Framework Convention on Climate Change) and a signatory of the Kyoto Protocol. It has also recently submitted Intended Nationally Determined Contributions (INDCs) under the Paris Agreement. According to the GHG inventory furnished for 
INDC, in 2014 to 2015, the total GHG emissions of Pakistan were $405 \mathrm{Mt} \mathrm{CO}_{2 \text {-eqv }}$, with a breakdown of five key sectors releasing these emissions. These sectors and respective emissions are energy (185.97 Mt $\mathrm{CO}_{2 \text {-eqv }}$ ), agriculture (174.56 $\left.\mathrm{Mt} \mathrm{CO}_{2 \text {-eqv }}\right)$, industrial processes $\left(21.85 \mathrm{Mt} \mathrm{CO}_{2 \text {-eqv }}\right)$, land-use change and forestry (10.39 $\mathrm{Mt} \mathrm{CO}_{2 \text {-eqv }}$ ), and waste (12.29 $\left.\mathrm{Mt} \mathrm{CO}_{2 \text {-eqv }}\right)$. The INDC submission further projected that the contribution of the energy sector in the total GHG emissions in the year 2030 would be $898 \mathrm{Mt}$ $\mathrm{CO}_{2 \text {-eqv }}$, given that the proposed energy projects are implemented [57]. Further, the government's future development plan titled "Pakistan's Vision-2025" envisage the addition of 25,000 MW of power generation capacity with an optimal energy fuel mix comprising of oil, gas, hydro, coal, nuclear, solar, wind, and biomass. It is also envisaged that the Diamer-Bhasha and Dasu dams will be completed during the plan period along with $6600 \mathrm{MW}$ of electricity from Gaddani Power Park and from Thar coal. The government plan is ambitious in adapting clean coal technologies for the coal-based plants [58].

It is recognized that Pakistan's power sector is one of the major contributors of GHG emissions due to fossil fuel-based thermal power generation [59]. In this context, the government's ambition of adopting clean coal technologies is important since coal is the most polluting fuel with increased $\mathrm{CO}_{2}, \mathrm{NO} \times\left(\mathrm{NO}+\mathrm{NO}_{2}\right)$, and $\mathrm{SO}_{2}$ emissions [60]. This is particularly important considering the fact that air pollutants and GHG co-emitted will have environmental impacts at all scales, including local, regional, or global $[40,44,55]$. The $\mathrm{CO}_{2}$ intensity of coal is the highest $\left(52 \mathrm{~kg} \mathrm{CO}_{2} / \mathrm{kWh}\right)$ when compared to other fuels, such as natural gas, nuclear, and renewables, having a $\mathrm{CO}_{2}$ intensity of $0.92 \mathrm{~kg} \mathrm{CO}_{2} / \mathrm{kWh}$ and almost 0 and $0 \mathrm{~kg} \mathrm{CO} / \mathrm{kWh}$, respectively. Thus, GHG emission reduction shall be challenging for Pakistan once the induction of more coal takes place for power generation in the future. Under the proposed plans, the total GHG emissions in the country are expected to reach $4621 \mathrm{MtCO}_{2 \text {-eqv }}$ in 2050, which were $347 \mathrm{MtCO}_{2 \text {-eqv }}$ in 2011. These emissions for 2011 included $158.10 \mathrm{Mt}$ of $\mathrm{CO}_{2}(54 \%)$, 111.60 Mt of $\mathrm{CH}_{4}(36 \%), 27.90 \mathrm{Mt}$ of $\mathrm{N}_{2} \mathrm{O}(9 \%), 2.17 \mathrm{Mt}$ of $\mathrm{CO}(0.75)$, and $0.93 \mathrm{Mt}$ of volatile organic carbon (VOC) (0.3\%). [61]. Ishaque [20] further estimated that by 2035, coal-based power plants shall be the highest source of GHG emissions ( $81.5 \%$ ) followed by LNG-fired power stations (9.5\%) in Pakistan.

Given the above facts, Pakistan needs to consider more specific measures for GHG emission reduction in the future. This is because the country should adhere to the steps mentioned in the submitted INDC to the 21st Conference of Parties (CoP21) held in December 2015 [56]. However, most importantly, because the domestic landscape and policies, such as the climate change policy of 2012 [62], envisage that efforts and measures, such as the following, should be taken to contain climate change:

- Renewable energy technologies will be promoted, such as solar, bio-energy, wind, and geothermal;

- The architecture of public sector buildings will be updated with the installation of solar panels, energy efficiency, and conservation protocols;

- The capacity of nuclear power will be raised following the highest safety standards;

- The undertaken capacity building on technological advances and switching conventional installation with pressurized-fluidized-bed-combustion (PFBC) and near-zero emission technologies (ZNETs) to utilize the vast coal reserves found in the south of Pakistan;

- It would be also useful to include these new technologies in future pulverized coal integrated gasification combined cycle (IGCC) systems of the country;

- It should ensure that new coal-based power plants' performance is optimized by designs, which could be retrofitted with carbon dioxide capture and storage (CCS);

- To undertake a carbon tax implementation regime to mitigate the rising pollution levels owing to fossil fuel combustion in the energy conversion process; and

- To provide incentives and support those projects that are willing to enhance the energy supply by adapting low-carbon fossil fuels, and opting for CCS technologies, waste heat recovery, co-generation, coal bed methane capture, and combined cycle power generation.

In order to achieve the abovementioned policy targets, the government is required to support local research groups, and promote and encourage climate finance schemes [56]. It is evident that with 
such initiative and support, various countries around the world have made GHG emission reduction a subject of concern, thereby promoting renewable energy technologies, such as wind, solar, geothermal, hydro, biomass, wave, and tidal energy [63].

\section{Overview of Energy and Electricity Sector in Pakistan}

Historically, Pakistan has been long relying on non-renewable energy resources (NREs) except some share of hydel energy to produce electricity. There are limited NREs in the country, thus a lot of fossil fuels are imported. A major chunk of these fuels is used to produce electricity, which is a major form of secondary energy used in various sectors of the economy. The country's leading energy experts from the Water and Power Development Authority (WAPDA) have stated that the electricity demand of the country will rise up to a 66 GW installed capacity in 2030 [64]. Contrary to these advisories, little initiative has so far been witnessed from the authorities responsible for balancing the demand-supply gap in the energy systems. This has resulted in a forced load shedding policy in the country causing a loss of 2.5 to 3 billion dollars every year due to an average 10 to $16 \mathrm{~h}$ of blackouts every day since 2007 [65].

It is further realized that for the past couple of years, the number of people being able to access electricity has augmented from $62.4 \%$ to $67.4 \%$ due to population growth [66]. At the same time, it is important to realize that the current energy crisis is not only in the form of electricity shortage but has affected other fuel supplies as well. For example, the supply of limited national gas to the one sector, such as the power sector, causes load management of the fuel in other sectors, e.g., domestic, industry, fertilizer, and transport sectors [67].

A change in the country's fuel mix has been observed in the past two decades (Figure 1), with large amounts of oil and petroleum products imported mainly for the operation of various thermal power plants. This has also resulted a change in the consumption of different fuels across various sectors (Figure 2), such as transport and industrial sectors [68]. As such, the country is under severe economic stress to spend a huge amount of the national exchequer towards the fuel import bill. The huge import bill (40\% of the country's total import) poses serious threats to the economy as it accounts for $20 \%$ of the foreign exchange being spent in the form of 14.5 billion US dollars on the import of fossil fuels [65]. Thus, in the context of energy security for Pakistan, where demand is on the rise and the availability of energy is poor, the amount of capital spent on the import of fossil fuels is a very critical fourth nation's economy.

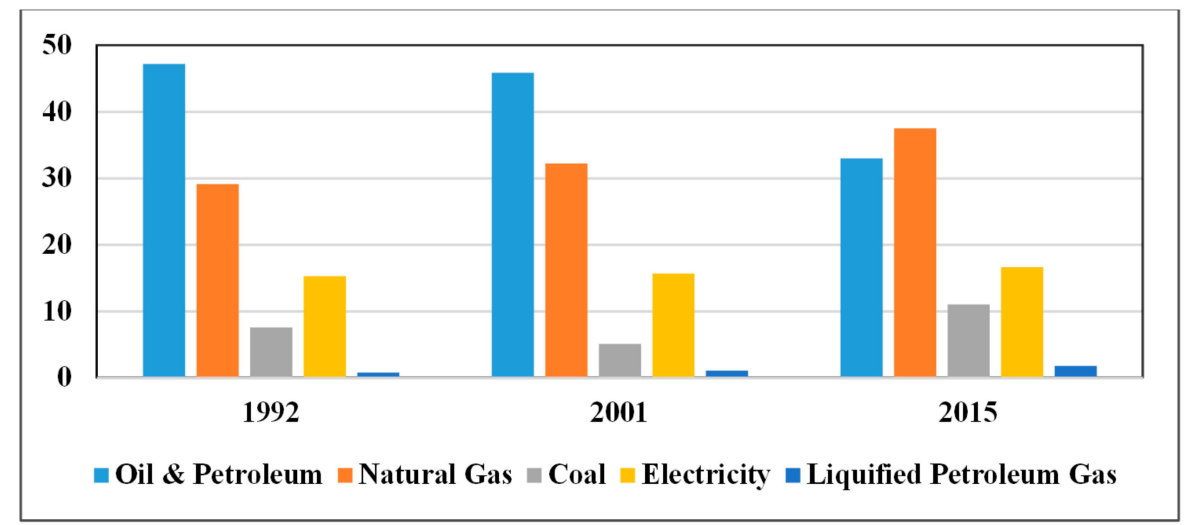

Figure 1. Historical energy fuel mix [69-73]. 


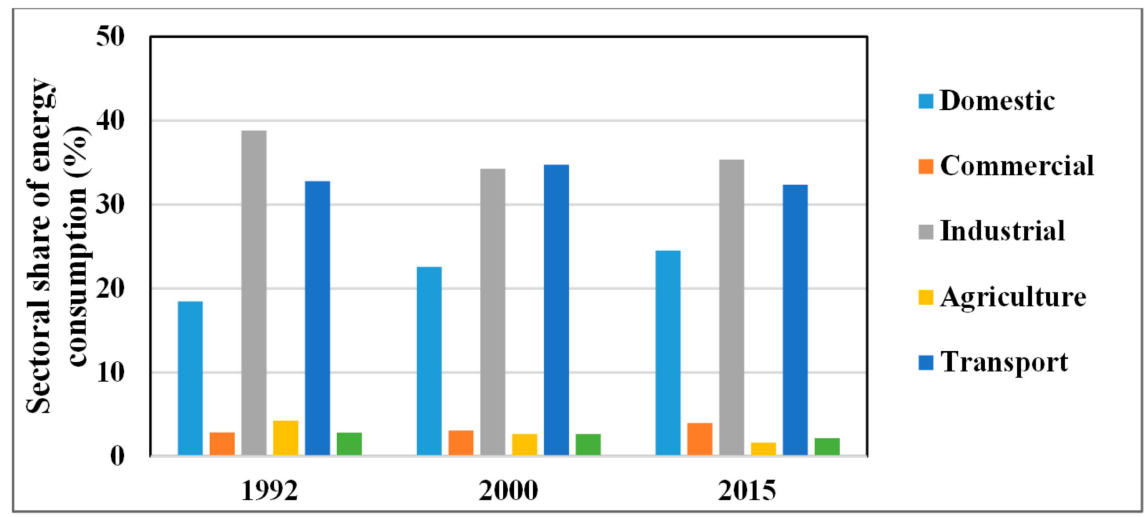

Figure 2. Historical sector-wise energy consumption [69-73].

In the meantime, $438 \mathrm{MW}$ of hydropower projects were added to the national grid in 2015, thus raising the country's total electricity generation to 106,966 GWh, which comprises thermal: $63.5 \%$; hydel: $30.4 \%$; nuclear: $5.4 \%$; and other renewables: $0.7 \%$ [73]. The current thermal power generation by the state-owned Wada's is 4900 MW (2142 MW from gas run stations, 2608 MW using oil, and 150 MW from coal-based power generation units). The combined capacity of KESC is 1946 MW, which comprises power plants fueled by oil and gas. On the other hand, the share of nuclear power plants administrated by Pakistan Atomic Energy Commission (PAEC) is only 787 MW [66]. Figure 3 shows electrical generation from different fuel sources in Pakistan's power sector during the last two decades.

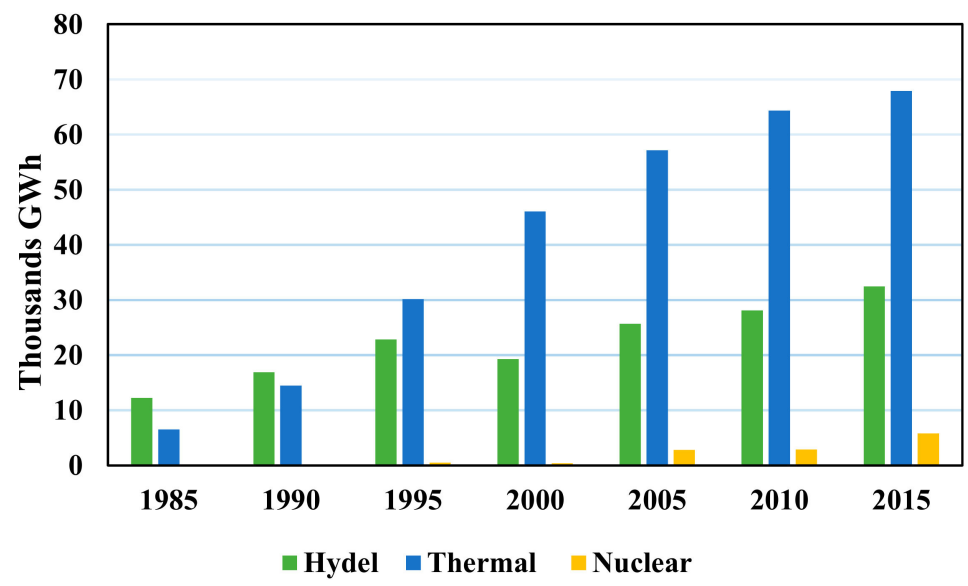

Figure 3. Electricity production by different sources in Pakistan from 1985 to 2015.

Shami, et al. [74] analyzed various loopholes for a poor electricity supply situation, with this not meeting the demand. They reported that in 2009, the power generation installed capacity was $9 \mathrm{GW}$, which was against the demand of $10 \mathrm{GW}$. During the summer, the demand further soared to $16.5 \mathrm{GW}$. As such, despite an additional capacity addition in the following years, in 2013, the demand-supply gap remained at $5 \mathrm{GW}$. The supply-side woes were further supplemented by the transmission and distribution (TD) losses, which often remained above the $20 \%$ level due to technical and non-technical reasons, including theft of electricity [75].

From the economic perspective, it is very unfortunate that despite steady growth in the GDP $(6 \%$ per year) from 2005 to 2007, the enhanced electricity demand could not be met, thus posing a negative impact on the economy in the following years, with electricity load shedding taking over the progress made. Eventually, 0.535 million people working in different industrial units lost their jobs, and a GDP loss of $2.5 \%$ and a total export loss of 1.3 billion USD were the consequences of electricity load shedding in the following years [76]. The consistent increase in the demand and thus a constant increase in the 
demand-supply gap since 2007 can be judged from the electricity generation, which remained at 14.6 TWh in 2007, 23.4 TWh in 2008, 27.2 TWh in 2009, 31.6 TWh in 2010, and 34.9 TWh in 2011 [66]. These electricity generation outputs were quite low compared to the demand, which were thus converted into a power shortfall of $5 \mathrm{GW}$ per day, thus the cost of this unmet demand was equal to the cost of shredded electricity for about 11 years [75].

In light of the huge import bill of fossil fuel, although it could not sufficiently help in meeting the energy demand, the government has decided to use domestic coal for electricity generation, which is a paradigm shift for the energy sector of Pakistan. The utilization of indigenous coal can be regarded as a good step in addressing the energy crisis and reduce mass frustration by supplying an ample electricity supply, yet the environmental impacts, especially in the form of air pollution, are worth noticing. It is, therefore, inevitable to assess the energy environment nexus for the Pakistan electricity sector in view of the government's proposed plan under various possibilities following precise and state-of-the-art energy and environment modeling and planning techniques, such as MARKAL, ANSWER-TIMES, and GAINS.

\section{Theoretical and Methodological Framework}

Energy planning is an important exercise of the socio-economic planning for a developing country, aiming at improving the quality of life. In this context, various energy modeling tools are used for energy planning across the globe. The selection of ANSWER-TIMES, a MARKAL family model, was based on the focus of this study to analyze the environmental and health impacts of different power generation scenarios, considering therein various fuel and technology mixes. This approach not only helped in ensuring sufficient electricity generation (demand-supply balance), but at the same time, the objective of "cleaner" and "cheaper" electricity was also attained. It is also pertinent to mention that MARKAL-based energy modeling and optimization is a widespread energy planning methodology adopted by more than 70 countries and various organizations around the globe [77-80]. The word MARKAL is an acronym for "MARKet Allocation". This model was developed earlier in 1974 by the International Energy Agency (IEA) following the oil crises of the 1970s. The underlying methodology of the MARKAL is based on the general algebraic modeling system (GAMS) [77]. The MARKAL-based modeling scheme allows the users to view and relate both the supply and demand side of the energy system, as such enabling the modeler to add macro-economic-related data at once. It is, therefore, the MARKAL model that addresses both engineering and economic aspects of energy accounting and modeling more effectively [81]. In addition, due to comprehensive parameterization in the model, it is classified as a bottom-up energy modeling framework that is capable of accounting environmental impacts form GHG emissions due to energy conversion processes [82]. It is important to mention that MARKAL is not based on the extrapolation of past data, which is reflected in the output results. Instead, technologies are described in the form of detailed parameters as input data alongside discrete economic data that has to come from outside. The output results are obtained when the model is set and run as a linear programming problem with cost minimization as an objective function.

In this study, the model's ANSWER-TIMES interface was used, which is a successor of the MARKAL and is based on similar principles but with the additional capability of being able to be used in the windows-based environment. The model developed in this study was named Pak-TIME since the TIMES environment of the MARKAL model was used $[77,83]$. The TIMES is a linear programming-based optimization model that computes the economic equilibrium, i.e., provides optimal results while end-users' energy is met using energy supply sources. As the model is run, following calibration, TIMES computes the solutions, and the demand is met using the available supply-side resources $[79,80,84]$. The TIMES platform of the model is extremely flexible as it provides the user with the opportunity to set upper and lower bounds and fix them in order to choose resources within desired limits of the modeler. In a similar fashion, the environmental targets, as per the choice of technologies, can be incorporated by setting the constraints in the model for each scenario [85]. The methodological flowchart of this study's model names as the Pak-TIMES is illustrated in Figure 4. 


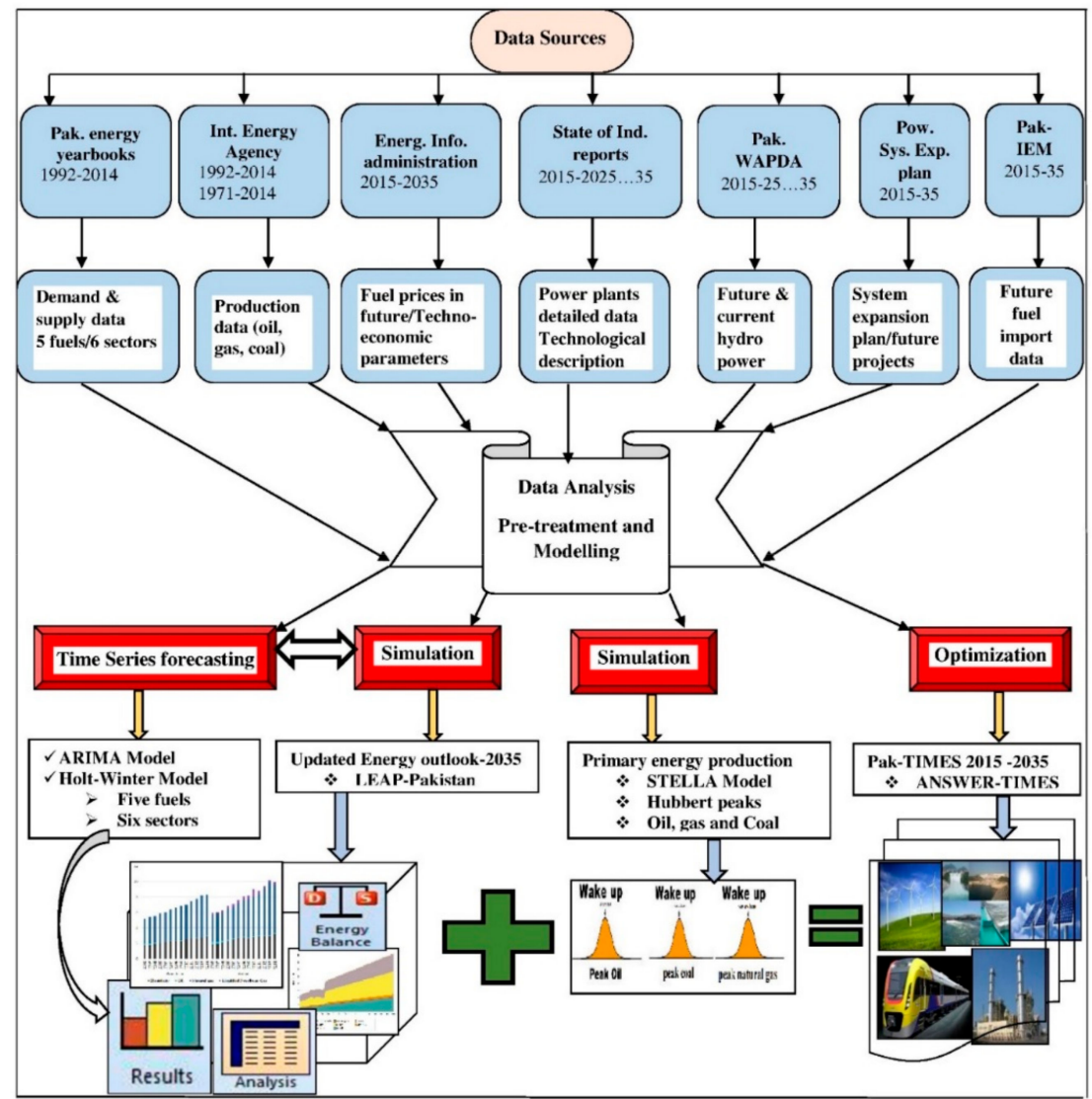

Figure 4. Methodological flowchart depicting the modeling approaches followed.

A significant amount of data and its pretreatment was undertaken in the course of the development of the Pak-TIMES, as shown (Figure 4). It is important to mention that we took emission coefficients/factors pertaining to the electricity generation processes from the GAINS Asia online model by narrowing down these parameters for Pakistan. Following is the summary of key modeling steps, which were accomplished in the Pak-TIMES model development process $[78,80]$ :

(i) Base year energy balance calibrations, including data pertaining to the consumption and production of all fuels used for power generation during the modeling period.

(ii) The primary energy supplies (domestic and imports) in consideration of costs of commodities, status, and updates of energy import projects, including design parameters, of these projects over the planning horizon.

(iii) Techno-economic data collection and arrangement of current and future projects, including annual generation, installed capacity and upcoming capacity additions, efficiency and availability, investment costs, activity costs, operation and maintenance costs, i.e., fixed and variable costs, the technical life, and finally the pollution and emission coefficients (factors) of each fuel and relevant technology.

(iv) The sectoral energy demand projections under each category of fuel and relevant technology.

The reference energy system was subsequently developed for the Pak-TIMES model as further described in the following sub-sections.

\subsection{The Reference Energy System of the Pak-TIMES Model}

The three key components of energy modeling are energy intake, i.e., the primary energy sources, the conversion process of primary energy into other forms of energy, i.e., in the usable forms of energy, and finally, the energy demand-side devices, i.e., the sectors and sub-sectors, which represent end-users, 
as illustrated in (Figure 5). All these key components of the energy system were represented for the base year data and called a reference energy system (RES) [85]. Figure 5 is representation of this RES and provides a convenient way to understand energy flows and their relationships within the energy system $[77,78,85]$.

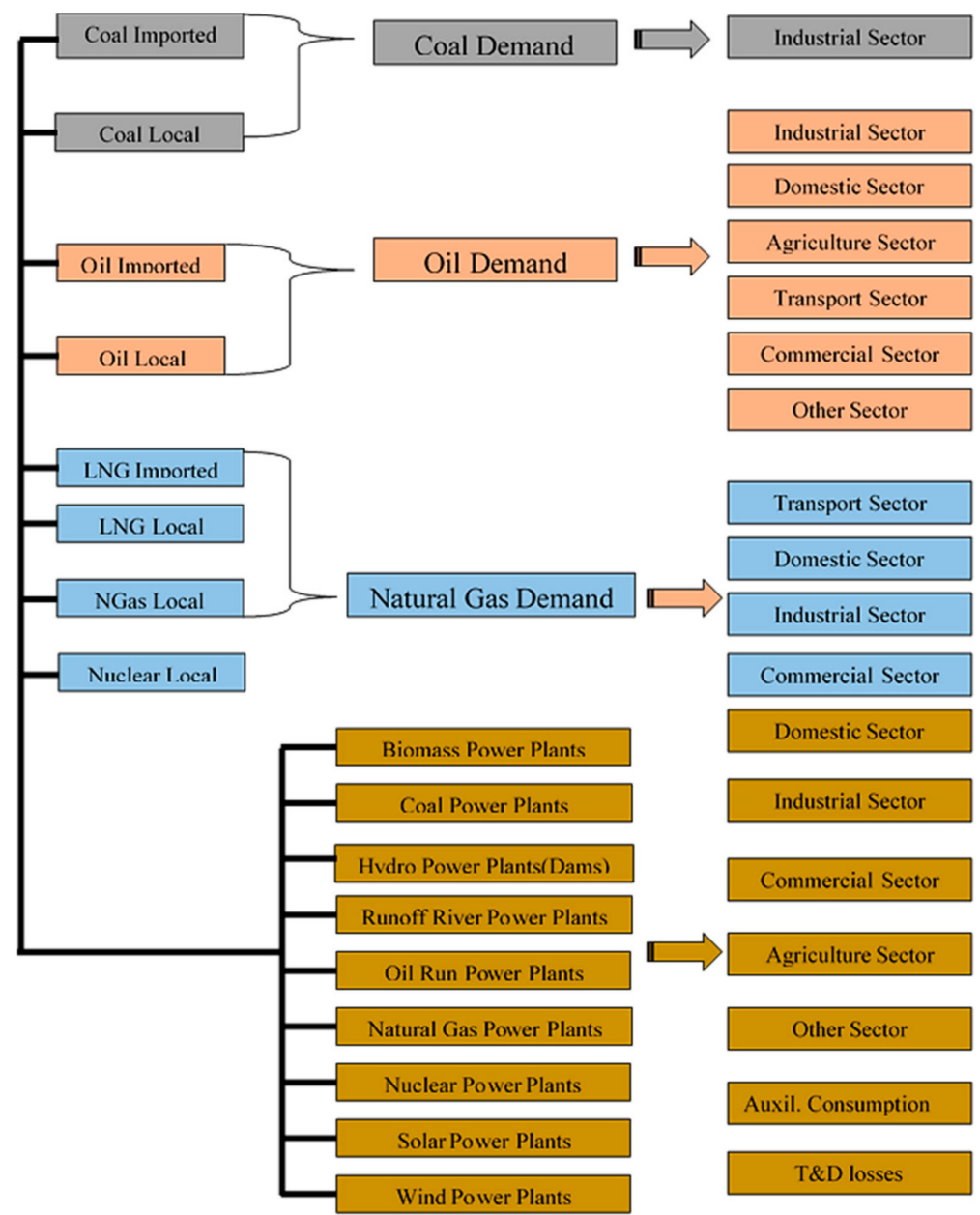

Figure 5. The reference energy system of the Pak-TIMES model.

The specified RES parameters led to the development and solution of various equations by the model, which altogether consider the whole energy system. In addition, while the model was run, the RES configurations were dynamically adjusted to determine the objective function and at the same time stratify the relevant equations and constraints. The minimization of the long-term discounted cost at a partial equilibrium point between demand and supply is the usual objective function of the MARKAL-TIMES model [79]. Further, in view of the anticipated results both for BAU and other scenarios, a set of constraints were applied in each case as per the resource and other considerations. Some of these constraints were general while the others could be specified depending on the modeler's objectives. Some key constraint parameters were given, as under [83,84]:

- The fulfillment of the demand for the study period under each scenario;

- No over and under production in each scenario, i.e., energy balance between supply and demand;

- The environmental emission limit setting while considering emission factor and taxes;

- The residual capacity transfer of the pre-existing technologies and capacity addition consideration for new technologies;

- Energy production capacity bounds and activity bounds; and

- Some other relevant constraint parameters. 
The following sub-sections further describe the generic details of the Pak-TIMES model as follows.

\subsection{Generic Details of the Pak-TIMES Model}

This study model was developed with the spirit of keeping this effort alive. As such, the technological, spatial, and temporal scale of the model can be improved over the period of time. The model in the current state depicts energy demand and supply across the six sectors of the economy. These sectors are domestic, industrial, agricultural, commercial, transport, and other government sectors. The energy resources considered in this study towards meeting the growing demand across these sectors include oil, natural gas, coal, LPG, and electricity. This study considered the planning period spanning from 2015 to 2035. The United States dollar (USD) based on the 2015 exchange rate was used as the currency in the model for monetary analysis. A $10 \%$ discounting rate was applied throughout the planning period whereas the energy unit used was the peta-joule (PJ). The key energy conversion process considered in the model was power generation as electricity is one of the major forms of final energy used across various sectors of the economy. A total of nine different electricity generation technologies were considered and modeled in Pak-TIMES. These included power generation from biomass, solar, wind, hydropower (dams), hydropower (run-of-river), coal-fired power plants, natural gas-run power plants, and oil-based thermal power plants. The energy demand and supply were further distinctly forecasted in initial studies, which include Rehman, et al. [86] and Rehman, et al. [87], thereby using different approaches. Nevertheless, the electricity demand forecast by the National Transmission and Dispatch Company (NTDC) NTDC [88] was input in this study model. This is because the NTDC forecasts are government projections and it is more realistic to address scenarios as close as possible to the existing government plans. All data sources mentioned in Figure 4 were followed to gather the required input data for the model. The emission coefficients (factors) of about 13 different pollutants were also considered, which included GHGs, $\mathrm{CO}_{2}, \mathrm{~N}_{2} \mathrm{O}$, and $\mathrm{CH}_{4}$, taken from the online version of the GAINS (Greenhouse Gas-Air Pollution Interactions and Synergies) Asia model. The results of this Pak-TIMES model for the BAU, RE-30 (30\% renewables without hydroelectricity), RE-40 (40\% renewables without hydroelectricity), Coal-30 (30\% coal-based electricity), and Coal-40 (40\% coal-based electricity) scenarios follows in the following section.

\section{Results}

In this Pak-TIMES model, the base year (2015) technologies for the power generation comprised of oil-based power stations (36.5\%), mega hydropower stations $(29.2 \%)$, natural gas-fired stations $(26.8 \%)$, nuclear power stations $(5.3 \%)$, wind power plants $(1.29 \%)$, micro hydel power stations $(0.90)$, biomass power stations $(0.30 \%)$, coal-fired power stations $(0.13 \%)$, and solar power stations $(0.02 \%)$. The government plans for power generation in the BAU scenario, however, it portrays significantly diverse fuel and technology mix for the study period as illustrated in (Figure 6). It is significant to note that an increased share of both small-scale run-of-river projects and large-scale hydropower dams may lead to the gradual replacement of oil and natural gas-fired power stations, including by coal, with a somewhat encouraging contribution from wind, solar, and biomass energy sources. A summary of the technological mix of power generation from the base year (2015) to the end year (2035) with an interval of 05 years for the BAU scenario is given in Table 1.

It is evident from the technological mix in the BAU scenario that governments plan to gradually reduce oil and replace it with coal and renewable-based technologies. As such, by the end of the planning period, in 2035, the oil-based electricity generation shall be zero. The emission analysis of the BAU scenario suggests that among all the air pollutants, the highest emissions will be that of $\mathrm{CO}_{2}$, followed by $\mathrm{PM}_{\mathrm{TSP}}, \mathrm{PM}_{10}, \mathrm{SO}_{2}$, and $\mathrm{PM}_{2.5}$ (Table 2). The total investment cost of the BAU scenario is estimated to be 170.5 billion USD in 2035 with aggregate GHG emissions of $181.5 \mathrm{Mt}$. 


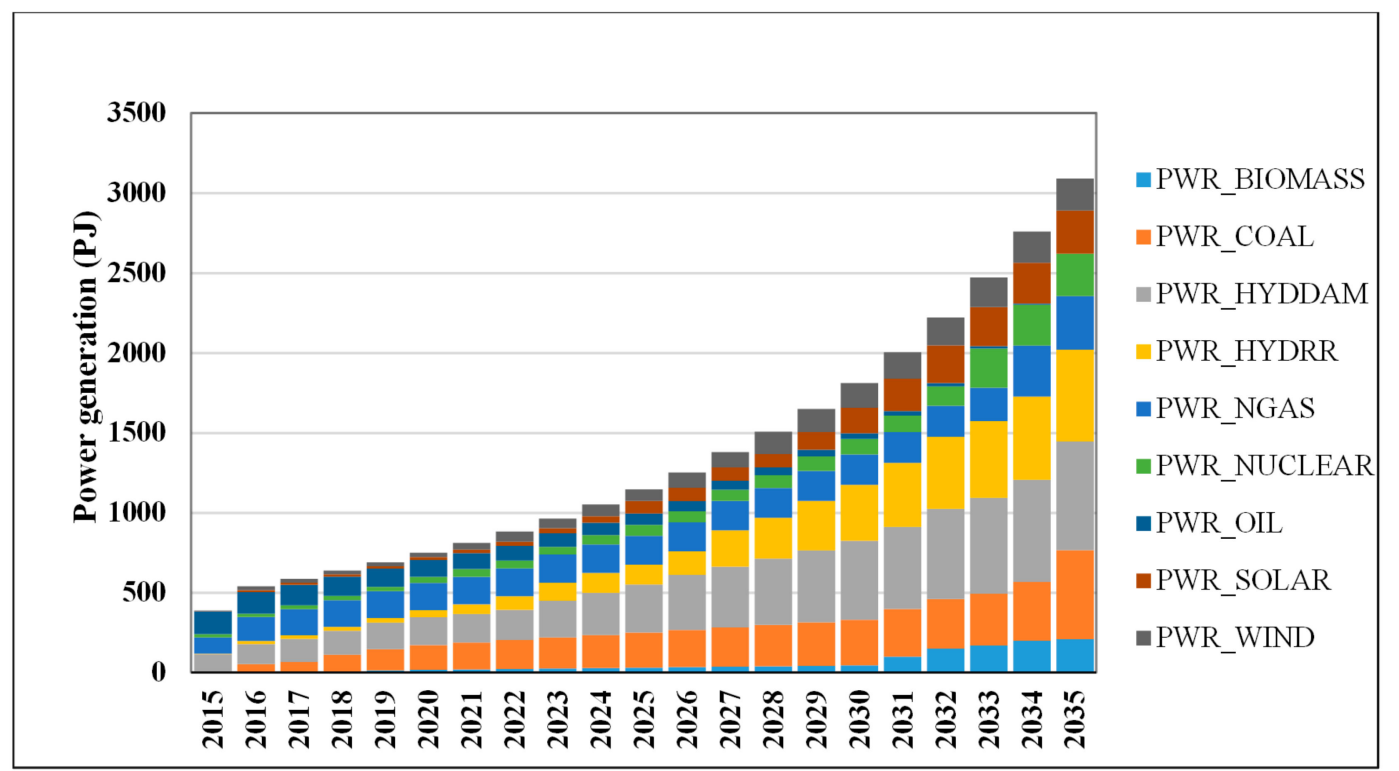

Figure 6. Increase in electricity generation (PJ) using various technologies (BAU scenario).

Table 1. Electricity production (PJ) and technological mix in BAU scenario.

\begin{tabular}{cccccc}
\hline Technologies & $\mathbf{2 0 1 5}$ & $\mathbf{2 0 2 0}$ & $\mathbf{2 0 2 5}$ & $\mathbf{2 0 3 0}$ & $\mathbf{2 0 3 5}$ \\
\hline Biomass-based Power stations & 1.15 & 17.67 & 31.78 & 45.89 & 210.00 \\
Coal-fired power stations & 0.52 & 154.76 & 219.84 & 284.92 & 556.06 \\
Run-of river Hydropower stations & 3.48 & 43.67 & 124.58 & 350.00 & 575.00 \\
Hydropower stations (dams) & 113.42 & 174.91 & 300.00 & 495.00 & 680.00 \\
Natural gas-fired power stations & 102.06 & 170.22 & 180.15 & 190.07 & 335.00 \\
Nuclear power stations & 20.89 & 37.93 & 69.05 & 96.50 & 265.00 \\
Oil-fired power stations & 141.79 & 106.34 & 70.90 & 35.45 & - \\
Solar power stations & 0.09 & 18.63 & 77.91 & 159.32 & 270.00 \\
Wind power stations & 5.00 & 26.00 & 73.04 & 155.00 & 200.00 \\
\hline
\end{tabular}

Table 2. Air pollutants emissions in BAU Scenario (kton).

\begin{tabular}{cccccc}
\hline $\begin{array}{c}\text { Pollutant } \\
\text { Species }\end{array}$ & $\mathbf{2 0 1 5}$ & $\mathbf{2 0 2 0}$ & $\mathbf{2 0 2 5}$ & $\mathbf{2 0 3 0}$ & $\mathbf{2 0 3 5}$ \\
\hline $\mathrm{CH}_{4}$ & 1.39 & 1.76 & 1.69 & 1.65 & 2.57 \\
$\mathrm{CO}$ & 7.83 & 108 & 149.09 & 190.18 & 367.82 \\
$\mathrm{CO}$ & $39,437.94$ & $80,043.72$ & $91,011.62$ & $101,979.5$ & $181,491.5$ \\
$\mathrm{~N}_{2} \mathrm{O}$ & 0.25 & 6.89 & 9.66 & 12.41 & 24.12 \\
$\mathrm{NO}$ & 103.89 & 232.98 & 271.19 & 309.4 & 557.77 \\
$\mathrm{PM}_{1}$ & 3.36 & 339.83 & 481.47 & 623.1 & 1214.98 \\
$\mathrm{PM}_{10}$ & 17.9 & 3917.13 & 5561.65 & 7206.17 & $14,061.38$ \\
$\mathrm{PM}_{2.5}$ & 7.09 & 1120.69 & 1590.08 & 2059.45 & 4017.65 \\
$\mathrm{PM}_{\mathrm{BC}}$ & 0.22 & 4.22 & 5.87 & 7.52 & 14.58 \\
$\mathrm{PM}_{\mathrm{OC}}$ & 0.21 & 23.5 & 33.3 & 43.12 & 84.08 \\
$\mathrm{PM}_{\mathrm{TSP}}$ & 26.69 & 6765.54 & 9608.29 & $12,451.06$ & $24,297.77$ \\
$\mathrm{SO}$ & 660.9 & 1983.7 & 2446.52 & 2909.34 & 5359.65 \\
$\mathrm{VOC}_{2}$ & 0.94 & 5.07 & 6.67 & 8.28 & 15.74 \\
\hline
\end{tabular}

This study is the first of its kind that explored the contribution of electricity generation processes towards atmospheric pollution, covering a wide range of air pollutants in the long run. Therefore, the estimated future emission of pollutants' electricity generation cannot be explicitly compared with other studies. However, the EDGAR (emissions database for global atmospheric research) GHG emission data for the base year 2015 can be comparatively analyzed as shown in 
Figure 7. The EDGAR estimates of the GHG emissions for 2015 pertaining to $\mathrm{CO}_{2}$ are $39,301.7 \mathrm{kton}$; for $\mathrm{N}_{2} \mathrm{O}, 0.31 \mathrm{kton}$; and for $\mathrm{CH}_{4}, 1.05$ kton [89]. Similarly, the results of this study estimated that in the base year 2015, $\mathrm{CO}_{2}, \mathrm{~N}_{2} \mathrm{O}$, and $\mathrm{CH}_{4}$ emissions were 39,437.9 kton, $0.25 \mathrm{kton}$, and $1.39 \mathrm{kton}$, respectively, which are close to the referred database.

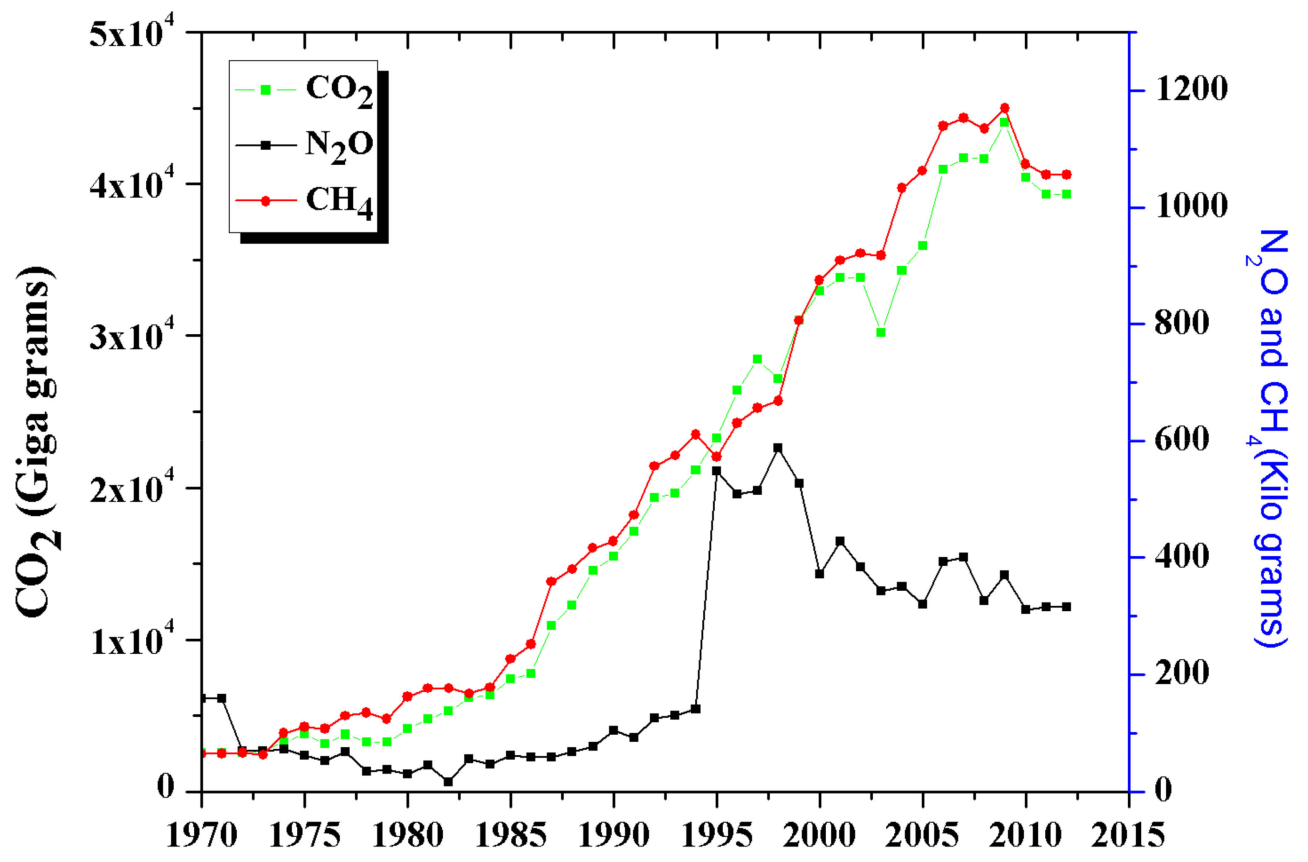

Figure 7. EDGAR estimates of the GHG emissions from the power sector in Pakistan.

It is also noted that for the BAU scenario, the share of coal-based power generation technologies in the base year 2015 is negligible at $0.13 \%$ only. However, in the following year in the BAU scenario, coal has a sufficient share with the gradual addition to match the scenario with government plans. As such, two coal-based scenarios for electricity generation have developed in this study with a marginal difference of $10 \%$ between these scenarios. The Coal-30 is the first of the coal-based scenarios wherein the share of coal in the overall energy for the electricity generation has been raised to a level of $30 \%$, which results in higher pollutant emissions compared to the BAU scenario as shown in Table 3.

Table 3. Air pollutants emissions in Coal-30 scenario (kton).

\begin{tabular}{cccccc}
\hline Pollutant Species & $\mathbf{2 0 1 5}$ & $\mathbf{2 0 2 0}$ & $\mathbf{2 0 2 5}$ & $\mathbf{2 0 3 0}$ & $\mathbf{2 0 3 5}$ \\
\hline $\mathrm{CH}_{4}$ & 1.44 & 1.85 & 1.88 & 2.35 & 3.15 \\
$\mathrm{CO}$ & 20.09 & 129.25 & 192.53 & 358 & 605.76 \\
$\mathrm{CO}$ & $44,254.36$ & $88,395.38$ & $108,079.4$ & $167,918.9$ & $260,085.2$ \\
$\mathrm{~N}_{2} \mathrm{O}$ & 1.07 & 8.31 & 12.55 & 23.6 & 40.14 \\
$\mathrm{NO}_{\mathrm{X}}$ & 119.22 & 259.55 & 325.49 & 519.17 & 815.71 \\
$\mathrm{PM}_{1}$ & 44.65 & 411.42 & 627.78 & 1188.38 & 2026.1 \\
$\mathrm{PM}_{10}$ & 495.78 & 4745.78 & 7255.11 & $13,748.63$ & $23,449.63$ \\
$\mathrm{PM}_{2.5}$ & 143.63 & 1357.45 & 2073.93 & 3928.76 & 6700.03 \\
$\mathrm{PM}_{\mathrm{BC}}$ & 0.72 & 5.08 & 7.63 & 14.3 & 24.31 \\
$\mathrm{PM}_{\mathrm{OC}}$ & 3.06 & 28.45 & 43.42 & 82.2 & 140.14 \\
$\mathrm{PM}_{\mathrm{TSP}}$ & 852.46 & 8197.43 & $12,534.55$ & $23,756.33$ & $40,520.53$ \\
$\mathrm{SO}$ & 841.61 & 2297.04 & 3086.87 & 5383.29 & 8892.55 \\
$\mathrm{VOC}_{2}$ & 1.45 & 5.96 & 8.48 & 15.27 & 25.49 \\
\hline
\end{tabular}

It may be noted that the percentage of coal in the Coal-30 scenario has been raised gradually from the base year level, under the BAU scenario, and marginally increasing for subsequent years as. $5 \%$ in $2015,15 \%$ in $2016-2017,20 \%$ in $2018-2019,25 \%$ in $2020-2025$, and $30 \%$ in $2026-2035$. These capacity 
additions under the Coal-30 scenario will require an estimated investment cost of 178.7 billion USD in 2035 and shall add 260.1 Mt of GHG to the atmosphere with electricity generation of $3091 \mathrm{PJ}$.

One possible explanation for the greater planned coal utilization by the government for power generation could be to avoid the cost incurred on import fuel since coal is abundantly found in the country. However, from an economic point of view, following the Coal-40 scenario until 2035 shall also require an estimated cumulative investment cost of 184.8 billion USD. In terms of total air pollutants emissions, including GHG emissions, the Coal-40 scenario is the worst, where 338.9 Mt of GHG emissions are estimated to be released into the atmosphere alongside other pollutants in their highest estimated magnitudes, as shown in (Table 4).

Table 4. Air pollutants emissions in the Coal-40 scenario (kton).

\begin{tabular}{cccccc}
\hline Pollutant Species & $\mathbf{2 0 1 5}$ & $\mathbf{2 0 2 0}$ & $\mathbf{2 0 2 5}$ & $\mathbf{2 0 3 0}$ & $\mathbf{2 0 3 5}$ \\
\hline $\mathrm{CH}_{4}$ & 1.5 & 1.95 & 2.03 & 2.84 & 3.98 \\
$\mathrm{CO}$ & 32.68 & 153.58 & 229.74 & 475.55 & 806.26 \\
$\mathrm{CO}$ & $49,203.82$ & $97,954.45$ & $122,698.9$ & $214,104.1$ & $338,865.3$ \\
$\mathrm{~N}_{2} \mathrm{O}$ & 1.91 & 9.93 & 15.03 & 31.44 & 53.51 \\
$\mathrm{NO}$ & 134.96 & 289.96 & 372 & 666.1 & 1066.34 \\
$\mathrm{PM}_{1}$ & 87.08 & 493.37 & 753.11 & 1584.31 & 2701.46 \\
$\mathrm{PM}_{10}$ & 986.87 & 5694.22 & 8705.65 & $18,331.11$ & $31,266.16$ \\
$\mathrm{PM}_{2.5}$ & 283.94 & 1628.44 & 2488.38 & 5238.06 & 8933.36 \\
$\mathrm{PM}_{\mathrm{BC}}$ & 1.23 & 6.06 & 9.13 & 19.05 & 32.41 \\
$\mathrm{PM}_{\mathrm{OC}}$ & 6 & 34.12 & 52.09 & 109.58 & 186.84 \\
$\mathrm{PM}_{\mathrm{TSP}}$ & 1701.05 & 9836.33 & $15,041.07$ & $31,674.76$ & $54,027.36$ \\
$\mathrm{SO}_{2}$ & 1027.3 & 2655.68 & 3635.38 & 7116.09 & $11,848.27$ \\
$\mathrm{VOC}$ & 1.98 & 6.97 & 10.03 & 20.17 & 33.85 \\
\hline
\end{tabular}

In addition to the BAU, Coal 30, and Coal-40 scenario, two renewable energy scenarios, RE-30 and RE-40, were also developed using the Pak-TIMEs model. Both RE-30 and RE-40 focus on indigenous resource utilization for cheaper and clearer electricity generation. The percentage share of electricity generation technologies in RE-30 and RE-40 were adjusted such that the overall contribution from solar, wind, and biomass-based energy was $30 \%$ and $40 \%$, respectively. However, these scenarios do not consider hydropower plants, i.e., large-scale hydropower (dams) and small-scale hydropower stations (run-off river projects) as renewable. It is because the fraction of these sources is already quite high $(\sim 30 \%)$ in the BAU scenario.

In the RE-30 scenario, the cumulative share of solar, wind, and biomass energy is $30 \%$. However, in each year, the model was forced to give realistic results based on the potential of each renewable resource that exists within the country. This is achieved by setting bounds (upper and lower) on production, followed by constraint adjustment at each year in the planning window. The percentage of renewables was thus gradually raised to $2 \%$ in $2015,10 \%$ in $2016-2020,20 \%$ in $2021-2025$, and 30\% in 2026-2035 in the RE-30 scenario. With other technologies in the RE-30 scenario forming the overall energy mix for power generation, the highest emissions for the end year 2035 are estimated from $\mathrm{CO}_{2}, 143.18 \mathrm{Mt}$, followed by $\mathrm{PM}_{\mathrm{TSP}}(17.72 \mathrm{Mt}), \mathrm{PM}_{10}(10.2 \mathrm{Mt}), \mathrm{SO}_{2}(3.92 \mathrm{Mt})$, and $\mathrm{PM}_{2.5}(2.93 \mathrm{Mt})$ as shown in Table 5.

The most environment friendly, and thus the cleanest, of all electricity generation pathways is the RE-40 scenario. This scenario assumes that the renewable energy percentage shall be raised further up to $40 \%$ by the end year 2035, which will result in an impressive reduction in air pollutant emissions. The estimated GHG emission in the RE-40 scenario is $96.01 \mathrm{Mt}$, which is half of the emissions in the BAU scenario, and around 3.52 times lower than the GHG emission in the Coal-40 scenario. Table 6 shows the air pollutant emissions in the RE-40 scenario. 
Table 5. Air pollutants emissions in the RE-30 scenario (kton).

\begin{tabular}{cccccc}
\hline Pollutant Species & $\mathbf{2 0 1 5}$ & $\mathbf{2 0 2 0}$ & $\mathbf{2 0 2 5}$ & $\mathbf{2 0 3 0}$ & $\mathbf{2 0 3 5}$ \\
\hline $\mathrm{CH}_{4}$ & 1.39 & 1.6 & 1.61 & 1.65 & 2.17 \\
$\mathrm{CO}$ & 7.83 & 70.53 & 129.73 & 190.18 & 270.31 \\
$\mathrm{CO}$ & $39,437.94$ & $65,321.96$ & $83,405.94$ & $101,979.5$ & $143,181.04$ \\
$\mathrm{~N}_{2} \mathrm{O}$ & 0.25 & 4.39 & 8.37 & 12.41 & 17.62 \\
$\mathrm{NO}$ & 103.89 & 186.15 & 246.99 & 309.4 & 435.89 \\
$\mathrm{PM}_{1}$ & 3.36 & 213.62 & 416.26 & 623.1 & 886.56 \\
$\mathrm{PM}_{10}$ & 17.9 & 2456.44 & 4807.02 & 7206.17 & $10,260.23$ \\
$\mathrm{PM}_{2.5}$ & 7.09 & 703.35 & 1374.47 & 2059.45 & 2931.59 \\
$\mathrm{PM}_{\mathrm{BC}}$ & 0.22 & 2.7 & 5.09 & 7.52 & 10.64 \\
$\mathrm{PM}_{\mathrm{OC}}$ & 0.21 & 14.77 & 28.8 & 43.12 & 61.37 \\
$\mathrm{PM}_{\mathrm{TSP}}$ & 26.69 & 4241.5 & 8304.3 & $12,451.06$ & $17,729.45$ \\
$\mathrm{SO}$ & 660.9 & 1431.36 & 2161.16 & 2909.34 & 3922.3 \\
$\mathrm{VOC}_{2}$ & 0.94 & 3.51 & 5.87 & 8.28 & 11.68 \\
\hline
\end{tabular}

Table 6. Air pollutants emissions in the RE-40 scenario (kton).

\begin{tabular}{cccccc}
\hline Pollutant Species & $\mathbf{2 0 1 5}$ & $\mathbf{2 0 2 0}$ & $\mathbf{2 0 2 5}$ & $\mathbf{2 0 3 0}$ & $\mathbf{2 0 3 5}$ \\
\hline $\mathrm{CH}_{4}$ & 1.39 & 1.48 & 1.5 & 1.49 & 1.46 \\
$\mathrm{CO}$ & 7.83 & 40.04 & 72.18 & 122.96 & 180.01 \\
$\mathrm{CO}$ & $39,437.94$ & $53,343.31$ & $65,081.04$ & $79,860.4$ & $96,001.18$ \\
$\mathrm{~N}_{2} \mathrm{O}$ & 0.25 & 2.36 & 4.48 & 7.88 & 11.73 \\
$\mathrm{NO}_{\mathrm{X}}$ & 103.89 & 148.04 & 186.42 & 236.76 & 292.01 \\
$\mathrm{PM}_{1}$ & 3.36 & 110.93 & 219.64 & 393.88 & 589.96 \\
$\mathrm{PM}_{10}$ & 17.9 & 1267.93 & 2531.15 & 4552.98 & 6827.69 \\
$\mathrm{PM}_{2.5}$ & 7.09 & 363.77 & 724.21 & 1301.39 & 1950.84 \\
$\mathrm{PM}_{\mathrm{BC}}$ & 0.22 & 1.47 & 2.73 & 4.77 & 7.08 \\
$\mathrm{PM}_{\mathrm{OC}}$ & 0.21 & 7.67 & 15.21 & 27.27 & 40.84 \\
$\mathrm{PM}_{\mathrm{TSP}}$ & 26.69 & 2187.76 & 4371.63 & 7866.39 & $11,798.1$ \\
$\mathrm{SO}$ & 660.9 & 981.94 & 1305.51 & 1911.02 & 2610.87 \\
$\mathrm{VOC}_{2}$ & 0.94 & 2.24 & 3.52 & 5.53 & 7.79 \\
\hline
\end{tabular}

The results of the analyses of all the Pak-TIMES model scenarios suggest that the Coal-40 scenario would not only be a source of maximum GHG emissions, it would also require the highest investment cost. The Coal-30 investment costs are, although, somewhat less than the RE-40 scenario yet the GHG emissions shall be only next to the Coal-40 scenario. The BAU scenario has the lowest estimated investment cost, owing to conventional technologies. However, the GHG emissions are sufficiently high following both the coal scenarios. The RE-30 and RE-40 are the almost favorable scenario in terms of lowering GHG emissions, which are otherwise too high under other scenarios. In this context, the RE-40 scenario is most favorable to follow, as estimated GHG emissions are the lowest in this scenario with modest investment costs for the study period. It is pertinent to refer the GHG emission reduction potential of RE-4 compared to RE-30 with some additional cost, which is not on the much higher side. A summary of the GHG emissions and investment costs across all the scenarios of this study is given in Table 7 .

The results of this study pertaining to GHG emission from different power generation scenarios are very significant, which provides a great insight into the future of Pakistan's power sector. The estimated GHG emissions from the BAU and coal scenario would significantly add to climate change, and various air pollutant emissions shall also adversely impact human health. Contrary to these results, the renewable energy scenarios are not only found favorable in terms of reducing GHG emissions, yet their investment costs are rational. Pakistan, therefore, essentially needs to consider renewable and clean energy technologies for power generation to reduce climate change and health risks associated with GHG and air pollutant emissions. This calls for a change in the overall behavior of various organizations and companies involved in energy production businesses. The ecological behavior of 
companies and how they adapt environment-friendly policies has been sufficiently reported in the latest studies, such as [90].

Table 7. GHG emissions and investment cost across various scenarios.

\begin{tabular}{ccccccc}
\hline Scenarios & Parameters & $\mathbf{2 0 1 5}$ & $\mathbf{2 0 2 0}$ & $\mathbf{2 0 2 5}$ & $\mathbf{2 0 3 0}$ & $\mathbf{2 0 3 5}$ \\
\hline \multirow{2}{*}{ BAU } & GHG Emissions & $39,439.58$ & $80,052.37$ & $91,022.97$ & $101,993.56$ & $181,518.23$ \\
& Investment Cost & 19.11 & 61.14 & 105.68 & 127.88 & 170.58 \\
\hline \multirow{2}{*}{ Coal-30 } & GHG Emissions & $44,256.87$ & $88,405.54$ & $108,093.82$ & $167,944.80$ & $260,128.47$ \\
& Investment Cost & 19.94 & 61.14 & 105.68 & 125.56 & 178.73 \\
\hline \multirow{2}{*}{ Coal-40 } & GHG Emissions & $49,207.23$ & $97,966.33$ & $122,716.00$ & $214,138.33$ & $338,922.77$ \\
& Investment Cost & 21.05 & 61.14 & 105.68 & 134.87 & 184.86 \\
\hline \multirow{2}{*}{ RE-30 } & GHG Emissions & $39,439.58$ & $65,327.95$ & $83,415.92$ & $101,993.56$ & $143,200.83$ \\
& Investment Cost & 19.11 & 62.39 & 107.45 & 132.15 & 173.33 \\
\hline \multirow{2}{*}{ RE-40 } & GHG Emissions & $39,439.58$ & $53,347.15$ & $65,087.02$ & $79,869.77$ & $96,014.37$ \\
& Investment Cost & 19.32 & 63.26 & 111.30 & 139.67 & 179.26 \\
\hline
\end{tabular}

GHG Emission: Ktons; Investment Cost: 2015 Billion USD.

\section{Conclusions and Recommendations}

This research was inspired by the lack of effective planning and assessment tools to be used for investigating the future health and environmental impacts of energy production processes in the country. The ANSWER-TIMES modeling framework provides the essential platform for accounting for air pollution impacts alongside the energy output of various technologies, which are in operation and planning. As such, the Pak-TIMES model of this study is the first-ever country-scale bottom-up energy and environment optimization planning effort for Pakistan. Although, Pak-TIME was not directly coupled with the GAINS model, however, the emission data used in this model were synthesized using GAINS Asia online version. The emission estimates of the Pak-TIMES model were the average of all streams of technologies sorted based on the input fuel, i.e., coal, oil, and natural gas. In the case of renewables, such as both small and large-scale hydropower schemes, biomass, solar, and wind, these were assumed to be environmentally neutral during their production phases.

The research concludes that both the Coal-30 and Coal-40 scenarios will pose severe impacts in terms of air pollution. Both Coal-30 and Coal-40 scenarios shall cause maximum emissions

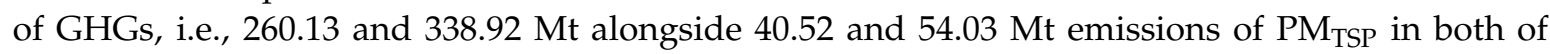
the scenarios, respectively. BAU scenario emissions were estimated to be $181.5 \mathrm{Mt}$ (GHGs) and 24.30 Mt $\left(\mathrm{PM}_{\mathrm{TSP}}\right)$. Minimum emissions were estimated in the RE-40 scenario, with $96.01 \mathrm{Mt}$ of

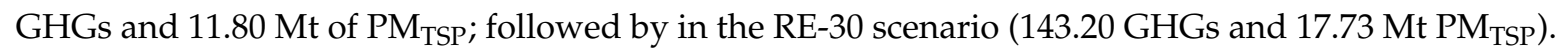
Henceforth, the environmentally ambitious RE-30 and RE-40 scenarios provide a greater reduction in the emissions and outlay technological combinations that can mitigate the negative impact on air quality. Thus, the results of this study support the thesis that increasing the share of coal in the energy fuel mix will result in the highest amount of air pollutants released into the atmosphere, namely various fractions of particulate matter; gaseous pollutants, such as $\mathrm{SO}_{2}, \mathrm{NO}_{X}, \mathrm{CH}_{4}$, and $\mathrm{CO}_{2}$. In economic terms, a cumulative investment cost of 170 billion USD shall be required to meet the electricity demand (3091 PJ) by 2035. Contrary to this, the most environmentally ambitious pathway, the RE-40 scenario, will require 179.2 billion USD of investment with significantly reduced GHG emissions. The Coal-40 scenario, on the other hand, will cause the highest amount of GHG emissions, with an estimated investment cost of 184.8 billion USD.

Hence, based on the results of this study, it is suggested that:

(i) Due to the associated environmental impacts of coal-based power plants to be installed in the future, it is crucial to not only compare the total system cost but also the environmental cost, once the public is exposed to the hazardous emissions of these power plants; 
(ii) The decision-makers shall take extreme precautions regarding the increasing share of coal-based power in the future fuel mix. From the analysis of the results of Pak-TIMES, it can be implied that coal-based power production pathways may become more economical than renewables for the reasons that currently, none of the renewable energy technologies are readily available in the country other than hydropower. Similarly, the varying international market prices of renewable technologies, although currently in a declining trend, may result in creating an import dilemma, i.e., import coal technology versus importing renewables;

(iii) It is therefore inevitable that Pakistan shall accelerate research and development for indigenization and manufacturing of renewable energy technologies. As such, short-sighted decision making, on the basis of the availability of fuel coal and potential of renewables, should not be undertaken. It is because the decision of today impacts the future layout of Pakistan's energy sector;

(iv) Hence, it is suggested that more detailed studies shall be carried out considering the environmental and levelized costs of different technologies; and

(v) The government and concerned ministries shall provide support and appreciate all research and development efforts to derive an optimal and effective energy plan for the future.

Similarly, due to the limited scope of this study, certain points related to the current study still need investigation for which the foundation has already been laid down, e.g., improved understanding of the energy-environment interaction, such as the following, would greatly help to continue efforts like this:

(i) Emission estimation and carbon footprint analysis at sectoral levels;

(ii) Setting up and assessing decarbonization pathways across various sectors of the economy;

(iii) Investigations based on life cycle inventory analysis revealing social and environmental cost of atmospheric pollution from the energy sector; and

(iv) Incorporation of carbon trading into an economic cost-benefit analysis of technological choices for climate change mitigation and adaptation in the energy sector and other such considerations.

Supplementary Materials: The following are available online at http://www.mdpi.com/1996-1073/13/1/108/s1, Table S1: A summary of the existing literature reporting air pollution status in Pakistan.

Author Contributions: All the authors contributed to this study. S.A.U.R., Y.C. conceptualized the study. S.A.U.R. managed data and used software in this study. N.H.M. and Z.A.S. analyzed the results and prepared draft of the study. S.A.U.R. and R.F. validated the results, and reviewed the draft. S.U.R.K. finalized the draft, undertook review and editing work of the study. All authors have read and agreed to the published version of the manuscript.

Funding: This research received no external funding.

Conflicts of Interest: The authors declare no conflict of interest.

\section{References}

1. Colbeck, I.; Nasir, Z.A.; Ali, Z. The state of ambient air quality in Pakistan-A review. Environ. Sci. Pollut. Res. Int. 2010, 17, 49-63. [CrossRef] [PubMed]

2. Shah, M.H.; Shaheen, N. Seasonal behaviours in elemental composition of atmospheric aerosols collected in Islamabad, Pakistan. Atmos. Res. 2010, 95, 210-223. [CrossRef]

3. Javed, W.; Wexler, A.S.; Murtaza, G.; Ahmad, H.R.; Basra, S.M.A. Spatial, temporal and size distribution of particulate matter and its chemical constituents in Faisalabad, Pakistan. Atmósfera 2015, 28, 99-116. [CrossRef]

4. Purohit, P.; Munir, T.; Rafaj, P. Scenario analysis of strategies to control air pollution in Pakistan. J. Integr. Environ. Sci. 2013, 10, 77-91. [CrossRef]

5. Shah, M.H.; Shaheen, N.; Jaffar, M.; Khalique, A.; Tariq, S.R.; Manzoor, S. Spatial variations in selected metal contents and particle size distribution in an urban and rural atmosphere of Islamabad, Pakistan. J. Environ. Manag. 2006, 78, 128-137. [CrossRef]

6. Niaz, Y. Ambient Air Quality Evaluation: A Comparative Study in China and Pakistan. Pol. J. Environ. Stud. 2015, 24, 1723-1732. [CrossRef] 
7. Ilyas, S.Z.; Khattak, A.I.; Nasir, S.M.; Qurashi, T.; Durrani, R. Air pollution assessment in urban areas and its impact on human health in the city of Quetta, Pakistan. Clean Technol. Environ. Policy 2009, 12, 291-299. [CrossRef]

8. Raja, S.; Biswas, K.F.; Husain, L.; Hopke, P.K. Source Apportionment of the Atmospheric Aerosol in Lahore, Pakistan. Water Air Soil Pollut. 2009, 208, 43-57. [CrossRef]

9. Aziz, A.; Bajwa, I.U. Minimizing human health effects of urban air pollution through quantification and control of motor vehicular carbon monoxide (CO) in Lahore. Environ. Monit. Assess. 2007, 135, 459-464. [CrossRef]

10. Ali, M.; Athar, M. Air pollution due to traffic, air quality monitoring along three sections of National Highway N-5, Pakistan. Environ. Monit. Assess. 2008, 136, 219-226. [CrossRef]

11. Sughis, M.; Nawrot, T.S.; Ihsan-ul-Haque, S.; Amjad, A.; Nemery, B. Blood pressure and particulate air pollution in schoolchildren of Lahore, Pakistan. BMC Public Health 2012, 12, 378. [CrossRef] [PubMed]

12. Shah, M.H.; Shaheen, N.; Jaffar, M. Characterization, source identification and apportionment of selected metals in TSP in an urban atmosphere. Environ. Monit. Assess. 2006, 114, 573-587. [CrossRef] [PubMed]

13. Nazir, R.; Shaheen, N.; Shah, M.H. Indoor/outdoor relationship of trace metals in the atmospheric particulate matter of an industrial area. Atmos. Res. 2011, 101, 765-772. [CrossRef]

14. Ali, M.; Athar, M. Impact of transport and industrial emissions on the ambient air quality of Lahore City, Pakistan. Environ. Monit. Assess. 2010, 171, 353-363. [CrossRef]

15. Shahid, M.Z. Seasonal Variations of Aerosols in Pakistan: Contributions of Domestic Anthropogenic Emissions and Transboundary Transport. Aerosol Air Qual. Res. 2015, 15, 1580-1600. [CrossRef]

16. Alam, K.; Khan, R.; Ali, S.; Ajmal, M.; Khan, G.; Muhammad, W.; Ali, M.A. Variability of aerosol optical depth over Swat in Northern Pakistan based on satellite data. Arab. J. Geosci. 2014, 8, 547-555. [CrossRef]

17. Shah, M.H.; Shaheen, N.; Nazir, R. Assessment of the trace elements level in urban atmospheric particulate matter and source apportionment in Islamabad, Pakistan. Atmos. Pollut. Res. 2012, 3, 39-45. [CrossRef]

18. Alam, K. Particulate Matter and Its Source Apportionment in Peshawar, Northern Pakistan. Aerosol Air Qual. Res. 2015, 15, 634-647. [CrossRef]

19. Ali, M.; Athar, M.; Khan, M.A.; Niazi, S.B. Hazardous Emissions from Combustion of Fossil Fuel from Thermal Power Plants Based on Turbine Technologies. Hum. Ecol. Risk Assess. Int. J. 2011, 17, 219-235. [CrossRef]

20. Ishaque, $\mathrm{H}$. Is it wise to compromise renewable energy future for the sake of expediency? An analysis of Pakistan's long-term electricity generation pathways. Energy Strategy Rev. 2017, 17, 6-18. [CrossRef]

21. Jalees, M.I.; Asim, Z. Statistical modeling of atmospheric trace metals in Lahore, Pakistan for correlation and source identification. Environ. Earth Sci. 2016, 75, 842. [CrossRef]

22. Guttikunda, S.K.; Jawahar, P. Atmospheric emissions and pollution from the coal-fired thermal power plants in India. Atmos. Environ. 2014, 92, 449-460. [CrossRef]

23. Sharma, R.; Pervez, Y.; Pervez, S. Seasonal evaluation and spatial variability of suspended particulate matter in the vicinity of a large coal-fired power station in India? A case study. Environ. Monit. Assess. 2005, 102, 1-13. [CrossRef] [PubMed]

24. Shahid, I.; Kistler, M.; Mukhtar, A.; Ramirez-Santa Cruz, C.; Bauer, H.; Puxbaum, H. Chemical composition of particles from traditional burning of Pakistani wood species. Atmos. Environ. 2015, 121, 35-41. [CrossRef]

25. Saeed, A.; Abbas, M.; Manzoor, F.; Ali, Z. Assessment of fine particulate matter and gaseous emissions in urban and rural kitchens using different fuels. J. Anim. Plant. Sci. 2015, 25, 687-692.

26. Irfan, M.; Riaz, M.; Arif, M.S.; Shahzad, S.M.; Saleem, F.; Rahman, N.-u.; van den Berg, L.; Abbas, F. Estimation and characterization of gaseous pollutant emissions from agricultural crop residue combustion in industrial and household sectors of Pakistan. Atmos. Environ. 2014, 84, 189-197. [CrossRef]

27. Tahir, S.N.; Rafique, M.; Alaamer, A.S. Biomass fuel burning and its implications: Deforestation and greenhouse gases emissions in Pakistan. Environ. Pollut. 2010, 158, 2490-2495. [CrossRef]

28. Jan, I.; Ullah, S.; Akram, W.; Khan, N.P.; Asim, S.M.; Mahmood, Z.; Ahmad, M.N.; Ahmad, S.S. Adoption of improved cookstoves in Pakistan: A logit analysis. Biomass Bioenergy 2017, 103, 55-62. [CrossRef]

29. Irfan, M.; Riaz, M.; Arif, M.S.; Shahzad, S.M.; Hussain, S.; Akhtar, M.J.; Berg, L.V.D.; Abbas, F. Spatial distribution of pollutant emissions from crop residue burning in the Punjab and Sindh provinces of Pakistan: Uncertainties and challenges. Environ. Sci. Pollut. Res. 2015, 22, 16475-16491. [CrossRef] 
30. Nasir, Z.A.; Colbeck, I.; Ali, Z.; Ahmed, S. Ultrafine particles in rural and urban dwellings with different household fuel use in developing countries-An example from Pakistan. J. Anim. Plant. Sci. 2015, 25, 693-699.

31. Adrees, M.; Ibrahim, M.; Shah, A.M.; Abbas, F.; Saleem, F.; Rizwan, M.; Hina, S.; Jabeen, F.; Ali, S. Gaseous pollutants from brick kiln industry decreased the growth, photosynthesis, and yield of wheat (Triticum aestivum L.). Environ. Monit. Assess. 2016, 188, 267. [CrossRef] [PubMed]

32. Ali, Z.; Rauf, A.; Sidra, S.; Nasir, Z.A.; Colbeck, I. Air Quality (Particulate Matter) at heavy traffic sites in Lahore, Pakistan. J. Anim. Plant. Sci. 2015, 25, 644-648.

33. Kamal, A.; Cincinelli, A.; Martellini, T.; Malik, R.N. Linking mobile source-PAHs and biological effects in traffic police officers and drivers in Rawalpindi (Pakistan). Ecotoxicol. Environ. Saf. 2016, 127, 135-143. [CrossRef] [PubMed]

34. Alam, K. Source Apportionment and Characterization of Particulate Matter (PM10) in Urban Environment of Lahore. Aerosol Air Qual. Res. 2014, 14, 1851-1861. [CrossRef]

35. Waheed, S.; Jaafar, M.Z.; Siddique, N.; Markwitz, A.; Brereton, R.G. PIXE analysis of $\mathrm{PM}_{2.5}$ and PM $2.5-10$ for air quality assessment of Islamabad, Pakistan: Application of chemometrics for source identification. J. Environ. Sci. Health Part A Toxic Hazard. Subst. Environ. Eng. 2012, 47, 2016-2027. [CrossRef]

36. Sepasgozar, S.M.E.; Li, H.; Shirowzhan, S.; Tam, V.W.Y. Methods for monitoring construction off-road vehicle emissions: A critical review for identifying deficiencies and directions. Environ. Sci. Pollut. Res. Int. 2019, 26, 15779-15794. [CrossRef]

37. Ul-Haq, Z.; Tariq, S.; Ali, M. Spatiotemporal patterns of correlation between atmospheric nitrogen dioxide and aerosols over South Asia. Meteorol. Atmos. Phys. 2016, 129, 507-527. [CrossRef]

38. Bibi, S.; Alam, K.; Chishtie, F.; Bibi, H.; Rahman, S. Temporal variation of Black Carbon concentration using Aethalometer observations and its relationships with meteorological variables in Karachi, Pakistan. J. Atmos. Sol. Terr. Phys. 2017, 157-158, 67-77. [CrossRef]

39. Bibi, S.; Alam, K.; Chishtie, F.; Bibi, H.; Rahman, S. Observations of black carbon aerosols characteristics over an urban environment: Radiative forcing and related implications. Sci. Total Environ. 2017, 603-604, 319-329. [CrossRef]

40. Lodhi, A.; Ghauri, B.; Khan, M.R.; Rahman, S.; Shafique, S. Particulate matter $\left(\mathrm{PM}_{2.5}\right)$ concentration and source apportionment in lahore. J. Braz. Chem. Soc. 2009, 20, 1811-1820. [CrossRef]

41. Shahid, I.; Kistler, M.; Mukhtar, A.; Ghauri, B.M.; Ramirez-Santa Cruz, C.; Bauer, H.; Puxbaum, H. Chemical characterization and mass closure of $\mathrm{PM}_{10}$ and $\mathrm{PM}_{2.5}$ at an urban site in Karachi-Pakistan. Atmos. Environ. 2016, 128, 114-123. [CrossRef]

42. Singh, N.; Murari, V.; Kumar, M.; Barman, S.C.; Banerjee, T. Fine particulates over South Asia: Review and meta-analysis of $\mathrm{PM}_{2.5}$ source apportionment through receptor model. Environ. Pollut. 2017, 223, 121-136. [CrossRef] [PubMed]

43. Stone, E.; Schauer, J.; Quraishi, T.A.; Mahmood, A. Chemical characterization and source apportionment of fine and coarse particulate matter in Lahore, Pakistan. Atmos. Environ. 2010, 44, 1062-1070. [CrossRef]

44. Alam, K.; Blaschke, T.; Madl, P.; Mukhtar, A.; Hussain, M.; Trautmann, T.; Rahman, S. Aerosol size distribution and mass concentration measurements in various cities of Pakistan. J. Environ. Monit. 2011, 13, 1944-1952. [CrossRef] [PubMed]

45. Colbeck, I. Exposure to $\mathrm{PM}_{10}, \mathrm{PM}_{2.5}, \mathrm{PM}_{1}$ and Carbon Monoxide on Roads in Lahore, Pakistan. Aerosol Air Qual. Res. 2011. [CrossRef]

46. Kamal, A.; Qamar, K.; Gulfraz, M.; Anwar, M.A.; Malik, R.N. PAH exposure and oxidative stress indicators of human cohorts exposed to traffic pollution in Lahore city (Pakistan). Chemosphere 2015, 120, 59-67. [CrossRef]

47. Shaheen, N.; Shah, M.H.; Khalique, A.; Jaffar, M. Metal levels in airborne particulate matter in urban Islamabad, Pakistan. Bull. Environ. Contam. Toxicol. 2005, 75, 739-746. [CrossRef]

48. Shah, M.H.; Shaheen, N. Statistical analysis of atmospheric trace metals and particulate fractions in Islamabad, Pakistan. J. Hazard. Mater. 2007, 147, 759-767. [CrossRef]

49. Shah, M.H.; Shaheen, N. Annual and Seasonal Variations of Trace Metals in Atmospheric Suspended Particulate Matter in Islamabad, Pakistan. Water Air Soil Pollut. 2007, 190, 13-25. [CrossRef]

50. Faiz, Y.; Tufail, M.; Javed, M.T.; Chaudhry, M.M.; Naila, S. Road dust pollution of Cd, Cu, Ni, Pb and Zn along Islamabad Expressway, Pakistan. Microchem. J. 2009, 92, 186-192. [CrossRef]

51. Ahmed, F.; Shah, M.H.; Shaheen, N. Diurnal and nocturnal variations of trace metals in urban atmospheric particulate matter from Islamabad, Pakistan. Environ. Earth Sci. 2013, 71, 817-826. [CrossRef] 
52. Siddique, N.; Waheed, S. Source apportionment using reconstructed mass calculations. J. Environ. Sci. Health Part A Toxic Hazard. Subst. Environ. Eng. 2014, 49, 463-477. [CrossRef] [PubMed]

53. Mansha, M.; Ghauri, B.; Rahman, S.; Amman, A. Characterization and source apportionment of ambient air particulate matter $\left(\mathrm{PM}_{2.5}\right)$ in Karachi. Sci. Total Environ. 2012, 425, 176-183. [CrossRef] [PubMed]

54. Shahid, M.Z.; Liao, H.; Qiu, Y.-L.; Shahid, I. Source Sector Contributions to Aerosol Levels in Pakistan. Atmos. Ocean. Sci. Lett. 2015, 8, 308-313. [CrossRef]

55. Mir, K.A.; Purohit, P.; Goldstein, G.A.; Balasubramanian, R. Analysis of baseline and alternative air quality scenarios for Pakistan: An integrated approach. Environ. Sci. Pollut. Res. Int. 2016, 23, 21780-21793. [CrossRef]

56. Lin, B.; Ahmad, I. Analysis of energy related carbon dioxide emission and reduction potential in Pakistan. J. Clean. Prod. 2017, 143, 278-287. [CrossRef]

57. INDC. Pakistan - Intended Nationally Determined Contribution, Submitted to COP21. Available online: http: //www4.unfccc.int/submissions/indc/Submission\%20Pages/submissions.aspx (accessed on 3 February 2018).

58. Vision. Pakistan 2025, One Nation-one Vision; Planning Commission, Ministry of Planning, Development \& Reforms, Government of Pakistan: Islamabad, Pakistan, 2014; p. 120.

59. Yousuf, I.; Ghumman, A.R.; Hashmi, H.N.; Kamal, M.A. Carbon emissions from power sector in Pakistan and opportunities to mitigate those. Renew. Sustain. Energy Rev. 2014, 34, 71-77. [CrossRef]

60. Shindell, D.; Faluvegi, G. The net climate impact of coal-fired power plant emissions. Atmos. Chem. Phys. 2010, 10, 3247-3260. [CrossRef]

61. Abas, N.; Kalair, A.; Khan, N.; Kalair, A.R. Review of GHG emissions in Pakistan compared to SAARC countries. Renew. Sustain. Energy Rev. 2017, 80, 990-1016. [CrossRef]

62. MOCC. National Climate Change Policy of Pakistan; Government of Pakistan, Ministry of Climate Change: Islamabad, Pakistan, 2012; p. 47.

63. Lu, W.C. Renewable energy, carbon emissions, and economic growth in 24 Asian countries: Evidence from panel cointegration analysis. Environ. Sci. Pollut. Res. Int. 2017, 24, 26006-26015. [CrossRef]

64. Zuberi, M.J.S.; Torkmahalleh, M.A.; Ali, S.M.H. A comparative study of biomass resources utilization for power generation and transportation in Pakistan. Int. J. Hydrog. Energy 2015, 40, 11154-11160. [CrossRef]

65. Uddin, W.; Khan, B.; Shaukat, N.; Majid, M.; Mujtaba, G.; Mehmood, A.; Ali, S.M.; Younas, U.; Anwar, M.; Almeshal, A.M. Biogas potential for electric power generation in Pakistan: A survey. Renew. Sustain. Energy Rev. 2016, 54, 25-33. [CrossRef]

66. Perwez, U.; Sohail, A.; Hassan, S.F.; Zia, U. The long-term forecast of Pakistan's electricity supply and demand: An application of long range energy alternatives planning. Energy 2015, 93, 2423-2435. [CrossRef]

67. Nayyar, Z.A.; Zaigham, N.A.; Qadeer, A. Assessment of present conventional and non-conventional energy scenario of Pakistan. Renew. Sustain. Energy Rev. 2014, 31, 543-553. [CrossRef]

68. HDIP. Pakistan Energy Yearbook; Hydrocarbon Development Institute of Pakistan: Islamabad, Pakistan, 2015; p. 142.

69. HDIP. Pakistan Energy Yearbook 1997; Hydrocarbon Development Institute of Pakistan, Ministry of Petroleum and Natural Resources, Government of Pakistan: Islamabad, Pakistan, 1998; p. 75.

70. HDIP. Pakistan Energy Yearbook 2002; Hydrocarbon Development Institute of Pakistan, Ministry of Petroleum and Natural Resources, Government of Pakistan: Islamabad, Pakistan, 2003; p. 91.

71. HDIP. Pakistan Energy Yearbook 2007; Hydrocarbon Development Institute of Pakistan, Ministry of Petroleum and Natural Resources, Government of Pakistan: Islamabad, Pakistan, 2008; p. 120.

72. HDIP. Pakistan Energy Yearbook 2012; Hydrocarbon Development Institute of Pakistan, Ministry of Petroleum and Natural Resources, Government of Pakistan: Islamabad, Pakistan, 2013; p. 125.

73. HDIP. Pakistan Energy Yearbook 2015; Hydrocarbon Development Institute of Pakistan, Ministry of Petroleum and Natural Resources, Government of Pakistan: Islamabad, Pakistan, 2016; p. 147.

74. Shami, S.H.; Ahmad, J.; Zafar, R.; Haris, M.; Bashir, S. Evaluating wind energy potential in Pakistan's three provinces, with proposal for integration into national power grid. Renew. Sustain. Energy Rev. 2016, 53, 408-421. [CrossRef]

75. Aslam, W.; Soban, M.; Akhtar, F.; Zaffar, N.A. Smart meters for industrial energy conservation and efficiency optimization in Pakistan: Scope, technology and applications. Renew. Sustain. Energy Rev. 2015, 44, 933-943. [CrossRef] 
76. Perwez, U.; Sohail, A. Forecasting of Pakistan's Net Electricity Energy Consumption on the Basis of Energy Pathway Scenarios. Energy Procedia 2014, 61, 2403-2411. [CrossRef]

77. Mondal, M.A.H. Implications of Renewable Energy Technologies in the Bangladesh Power Sector: Long-Term Planning Strategies; Zentrum für Entwicklungsforschung (ZEF), Abteilung Ökologie und Ressourcennutzung (ZEFc): Bonn, Germany, 2010.

78. Wright, E.L.; Belt, J.A.B.; Chambers, A.; Delaquil, P.; Goldstein, G. A scenario analysis of investment options for the Cuban power sector using the MARKAL model. Energy Policy 2010, 38, 3342-3355. [CrossRef]

79. Al-Riffai, P.; Breisinger, C.; Mondal, A.H.; Ringler, C.; Wiebelt, M.; Zhu, T. Linking the Economics of Water, Energy, and Food: A Nexus Modeling Approach; The International Food Policy Research Institute's (IFPRI) Egypt Strategy Support Program (Egypt SSP): Washington, DC, USA; Cairo, Egypt, 2017; p. 33.

80. Mondal, M.A.H.; Bryan, E.; Ringler, C.; Rosegrant, M. Ethiopian power sector development: Renewable based universal electricity access and export strategies. Renew. Sustain. Energy Rev. 2017, 75, 11-20. [CrossRef]

81. Anwar, J. Analysis of energy security, environmental emission and fuel import costs under energy import reduction targets: A case of Pakistan. Renew. Sustain. Energy Rev. 2016, 65, 1065-1078. [CrossRef]

82. Subramanyam, V.; Kumar, A.; Talaei, A.; Mondal, M.A.H. Energy efficiency improvement opportunities and associated greenhouse gas abatement costs for the residential sector. Energy 2017, 118, 795-807. [CrossRef]

83. Valasai, G.D. Modelling and Analysis of the Least Cost Power Generation Options for Pakistan; Mehran University of Engineering \& Technology Jamshoro: Jamshoro, Pakistan, 2017.

84. Mondal, A.H.M.; Mathur, J.; Denich, M. Impacts of $\mathrm{CO}_{2}$ emission constraints on technology selection and energy resources for power generation in Bangladesh. Energy Policy 2011, 39, 2043-2050. [CrossRef]

85. Mondal, M.A.H.; Mezher, T. Application of energy optimization models to design sustainable energy system: A review. Eng. J. Appl. Scopes 2017, 2, 1-8.

86. Rehman, S.; Cai, Y.; Fazal, R.; Das Walasai, G.; Mirjat, N. An Integrated Modeling Approach for Forecasting Long-Term Energy Demand in Pakistan. Energies 2017, 10, 1868. [CrossRef]

87. Rehman, S.; Cai, Y.; Mirjat, N.; Walasai, G.; Shah, I.; Ali, S. The Future of Sustainable Energy Production in Pakistan: A System Dynamics-Based Approach for Estimating Hubbert Peaks. Energies 2017, 10, 1858. [CrossRef]

88. NTDC. Electricity Demand Forecast. Based on Multiple Regression; Power Planning Wing: Islamabad, Pakistan, 2014; p. 111.

89. Janssens-Maenhout, G.; Crippa, M.; Guizzardi, D.; Muntean, M.; Schaaf, E.; Dentener, F.; Bergamaschi, P.; Pagliari, V.; Olivier, J.G.J.; Peters, J.A.H.W.; et al. Global Atlas of the three major Greenhouse Gas Emissions for the period 1970-2012. Earth System Science Data. Available online: http://edgar.jrc.ec.europa.eu/ overview.php?v=432\&SECURE=123;https://data.europa.eu/doi/10.2904/JRC_DATASET_EDGAR (accessed on 31 January 2018).

90. Liu, X.; Zhou, J.; Xue, Y.; Qian, S. Analysis of property management ecological behavior in China based on the grounded theory: The influencing factors and the behavior model. J. Clean. Prod. 2019, 235, 44-56. [CrossRef]

(C) 2019 by the authors. Licensee MDPI, Basel, Switzerland. This article is an open access article distributed under the terms and conditions of the Creative Commons Attribution (CC BY) license (http://creativecommons.org/licenses/by/4.0/). 